\author{
Jerzy Gaul (D)
}

Archiwum Główne Akt Dawnych, Warszawa

\title{
JÓZEF PIŁSUDSKI NA PROGU NIEPODLEGEOŚCI POLSKI
}

\section{ZWYCIĘSKI MĄŻ STANU - PRZEGRANY POLITYK (1914-1922) ${ }^{1}$}

\author{
Abstract \\ JÓZEF PIESUDSKI AT THE WAKE OF POLAND'S INDEPENDENCE - \\ A SUCCESSFUL STATESMAN AND LOST POLITICIAN
}

Piłsudski's engagement in the creation of the Polish military and independence movement in the years 1914-1922 established his position not only as a commander, leader, 'moral dictator', but also a statesman. Yet, the more Piłsudski let himself be driven by high reasons, instead of personal issues, the more he lost as a soldier and politician. He paid a high price for his moral convictions, which limited the margin of loyalty and the possibility of compromise, as well as removed the possibility of resigning from the program of struggle for the Polish state and its army.

Key words: Józef Piłsudski, statesman, dictator, World War I, reborn Poland

Słowa kluczowe: Józef Piłsudski, mąż stanu, dyktator, I wojna światowa, Polska odrodzona

\footnotetext{
Jest to rozszerzona polska wersja referatu „Józef Piłsudski an der Schwelle zur Unabhängigkeit Polens. Siegreich als Staatsmann - besiegt als Politiker (1914-1922)" wygłoszonego 9 listopada 2018 r. na konferencji „1918 - Das letzte Kriergsjahr” zorganizowanej przez Stację Naukową PAN i Heeresgeschichtliches Museum w Wiedniu, i artykułu opublikowanego w: 1918 - Das letzte Kriegsjahr. Symposium 9. November 2018, Wien 2019, s. 63-97.
} 
Cate życie walczytem o znaczenie tego, co się zwie imponderabilia - jak honor, cnota, męstwo i w ogóle sity wewnętrzne cztowieka, a nie dla starania o korzyści wtasne czy swojego najbliższego otoczenia.

Józef Piłsudski, 13 maja 1926 r. ${ }^{2}$

Odzyskanie przez Polskę niepodległości w listopadzie 1918 r. było procesem złożonym, w którym wzięli udział przedstawiciele organizacji wojskowych, stronnictw politycznych, stowarzyszeń oraz obywatele. Nie do przecenienia była rola Józefa Piłsudskiego, niekwestionowanego przywódcy ${ }^{3}$ obozu niepodległościowego, który po przyjeździe 10 listopada 1918 r. do Warszawy został Naczelnikiem Państwá ${ }^{4}$ Szybkie zdobycie władzy, o którą, jak twierdził, nie zabiegat5 ${ }^{5}$, rodzi pytania: dlaczego Naczelnikiem został Piłsudski, a nie inny generał czy polityk ${ }^{6}$; dlaczego jesienią 1918 r. właśnie w nim widziano męża opatrznościowego, który sprosta trudom odbudowy państwa polskiego?

W literaturze różnie oceniano nominację Piłsudskiego. Wątkiem łączącym zwolenników i krytyków Marszałka był pobyt w Magdeburgu dla uzyskania statusu bohatera narodowego ${ }^{7}$, nie zawsze dostatecznie akcentowanego osiągnięciami przed aresztowaniem ${ }^{8}$. Dla niemałej części społeczeństwa Piłsudski w latach 1914-1917 był wojskowym i politykiem, przywódcą obozu niepodległościowego i „dyktatorem moralnym”, który realizował program niepodległościowy: budowy armii polskiej i odbudowy państwa w latach 19141918 oraz utrwalenia jego niepodległości w okresie 1918-1922.

2 J. Piłsudski, Pisma zbiorowe, t. IX, Warszawa 1937, s. 9.

3 Według Gustava Le Bona „rola wielkich przywódców polega przede wszystkim na budzeniu wiary, czy to religijnej, politycznej lub społecznej, czy wreszcie wiary w jakieś dzieło, w człowieka bądź w ideę". Id e m, Psychologia ttumu, tłum. B. Ka prow icki, Kęty 2005, s. 58-59; M. Król, Wielcy wtadcy, Warszawa 2014.

4 J. Pajewski, Odbudowa państwa polskiego 1914-1918, Warszawa 1978, s. 293-301.

5 J. Piłsudski, Pisma zbiorowe, t. VI, s. 24-28.

6 Płk Kazimierz Sosnkowski był wybitnym działaczem niepodległościowym, szefem sztabu 1 pp i I Brygady Legionów Polskich, członkiem POW, więźniem w Magdeburgu, a mimo to nikt nie myślał o obdarzeniu go godnością Naczelnika Państwa. M. Le c zyk, Druga Rzeczypospolita 1918-1939. Spoteczeństwo. Gospodarka. Kultura. Polityka, Warszawa 2006, s. 55-56; J. Paje wski, Budowa Drugiej Rzeczypospolitej 19181926, Poznań 2007, s. 35-36.

7 B. Hutten-Czap ski, Sześ́́dziesiąt lat życia politycznego i towarzyskiego, t. II, Warszawa 1936, s. 597; W. Ję d rzejewicz, O Pitsudskim, Legionach i POW w PRL, „Zeszyty Historyczne” 1985, z. 74, s. 199; A. Frisz ke, O ksztatt niepodlegtej, Kraków 1989, s. 63; W. Su le ja, Józef Pitsudski, Wrocław-WarszawaKraków 1995, s. 171-175; A. Garlicki, Józef Pitsudski 1867-1935, Kraków 2009, s. 302; B. Ur b a n kow ski, Józef Pitsudski: marzyciel i strateg, Poznań 2014, s. 227-237.

8 G. Nowik, Odrodzenie Rzeczypospolitej w myśli politycznej Józefa Pitsudskiego 1918-1922. Część I - Sprawy wewnętrzne, Warszawa 2018, s. 108-121.

9 Tak określali Piłsudskiego jego żołnierze w lipcu 1917 r. J. Gau l, Czarno-żótty miraż. Sprawa Józefa Pitsudskiego w monarchii habsburskiej 1896-1918, Warszawa 2018, s. 239-295. 
Piłsudski był komendantem strzelców, walczył w Legionach Polskich na czele 1 Pułku Piechoty i I Brygady. Pod koniec 1916 r. przyjął godność członka Tymczasowej Rady Stanu (TRS) i był przewodniczącym Komisji Wojskowej. W czerwcu 1917 r. został honorowym przewodniczącym zjazdu wojskowych Polaków w Rosji ${ }^{10}$. Po powrocie z Magdeburga otrzymał od Rady Regencyjnej 10 listopada pełnię władzy wojskowej i 14 listopada 1918 r. politycznej jako Tymczasowy Naczelnik Państwa, w lutym 1919 r. został obdarzony przez Sejm godnością Naczelnika Państwa. Oprócz uznania i sławy Piłsudski zaliczył wiele porażek. Poznał gorycz likwidacji ruchu strzeleckiego w sierpniu 1914 r., dymisji z Legionów Polskich we wrześniu 1916 r., aresztowania przez Niemców 22 lipca 1917 r. Towarzyszyły temu dobrowolne rezygnacje: złożenie podania o dymisję z Legionów Polskich w lipcu 1916 r., wystąpienie z TRS w lipcu 1917 r., wycofanie się w grudniu 1922 r. z kandydowania na urząd prezydenta Rzeczypospolitej, rezygnacja w maju 1923 r. z funkcji szefa Sztabu Generalnego, a w czerwcu 1923 r. z przewodniczenia Ścisłej Radzie Wojennej. Co oznaczały te wzloty i upadki w życiu Piłsudskiego? Dlaczego decydował się na sprzeciw lub odmowę? Gdzie przebiegały granice kompromisu?

Autor niniejszego artykułu stawia tezę, że Piłsudski dzięki zaangażowaniu w tworzenie czynu zbrojnego i niepodległościowego zdobył pozycję nie tylko wodza, przywódcy obozu niepodległościowego i „dyktatora moralnego”, ale także męża stanu ${ }^{11}$. Miało to nieraz dramatyczne konsekwencje. Im bardziej Piłsudski stawał się mężem stanu ${ }^{12}$ i kierował się racjami wyższymi niż interes osobisty czy partyjny ${ }^{13}$, tym bardziej przegrywał jako wojskowy i polityk. Płacił cenę za trwanie przy imponderabiliach ${ }^{14}$, które zawężały granice lojalności i możliwości zawierania kompromisu oraz wykluczały rezygnację z programu

10 A. Miodowski, Sprawozdanie z I Ogólnego Zjazdu Delegatów Wojskowych Polaków w Rosji (7.0622.06.1917 r.), „Studia Podlaskie” 2000, t. 10, s. 233-279; M. Wrzosek, Polski czyn zbrojny podczas pierwszej wojny światowej 1914-1918, Warszawa 1990, s. 310-316; J. S n o p ko, Finat epopei Legionów Polskich 1916-1918, Białystok 2008, s. 165-166.

11 Mąż stanu jest czymś więcej niż wybitnym politykiem czy dyplomatą. Staje się nim, jeśli jego postępowanie jest warunkowane przez racje wyższe niż osobiste i partyjne. Według Friedricha von Meinecke „mąż stanu musi działać w harmonii z raison d'état. Aby cieszyć się wolnością i niepodległością państwo musi przestrzegać praw dyktowanych przez swoją własną rację stanu". A. R z e go cki, Racja stanu a polska tradycja myślenia o polityce, Kraków 2008, passim. Piłsudski mówił o sobie 12 lutego 1920 r. jako o mężu stanu - id e m, Pisma zbiorowe, t. V, s. 147. Nie miał dobrego zdania o dyplomatach i mężach stanu, zwłaszcza w kontekście prawdomówności - i d e m, Pisma zbiorowe, t. VIII, s. 305. Dla Piłsudskiego wzorem żołnierza i męża stanu był Napoleon. P. R z e w u sk i, Filozofia Pitsudskiego, Warszawa 2018, s. 111.

12 Dla J. Moraczewskiego Komendant był mężem stanu, „tak samo jak Waszyngton, jak Garibaldi”. Id e m, Przewrót w Polsce, Warszawa 2015, s. 61-62. Zob. G. Now i k, Odrodzenie Rzeczypospolitej..., s. 24-33, 108120.

13 Imponderabilia odgrywały w życiu Piłsudskiego ogromną rolę. I d e m, Pisma zbiorowe, t. IX, s. 9; S. S k w a r czy ńs ki, Przemiany duchowe Józefa Pitsudskiego w latach 1905-1922, „Niepodległośc” 1976, t. 10, s. 3; A. Rzegocki, Racja stanu..., s. 53, 308-310.

14 Imponderabilia (łac. imponderabilis), czyli wartości fundamentalne i zasady niezbędne do przetrwania wspólnoty politycznej, związane z racją stanu. A. R ze go cki, Racja stanu..., s. 53. 
odbudowy niepodległej Polski. W latach Wielkiej Wojny w sferze wojskowości były to zmagania o wskrzeszenie tradycji orężnej Rzeczypospolitej i utrzymanie morale wojska, w sferze politycznej - o powołanie narodowego rządu i sejmu oraz o poczuwanie się do odpowiedzialność za ludzi, którzy mu zaufali ${ }^{15}$. W pierwszych latach niepodległości racja stanu w sferze wojskowej wymagała budowy armii i zapewnienia jej spoistości i karności, w sferze politycznej odbudowy państwa i obrony jego granic oraz ustanowienia porządku demokratycznego i konstytucyjnego. Piłsudski nie zapominał o cywilizacyjnym wymiarze racji stanu, która wymagała trwałego związania Polski z nowoczesną cywilizacją Zachodu i kultywowania jej wartości ${ }^{16}$. Trwanie przy imponderabiliach, takich jak honor, wolność, swoboda, prawo, sprawiedliwość, determinowało stosunek Piłsudskiego do elit oraz społeczeństwa, które oceniał negatywnie, i nie starał się on o łatwy poklask ${ }^{17}$. Porywał ludzi nie słowami, lecz czynami i wartościami, którym był wierny ${ }^{18}$.

Powyższe zagadnienia zostaną omówione w trzech częściach chronologiczno-problemowych: wypełniania przez Piłsudskiego funkcji Komendanta, Brygadiera i wodza od sierpnia 1914 do września 1916 r.; „dyktatora moralnego” od października 1916 do października 1918 r.; Tymczasowego Naczelnika Państwa z kompetencjami dyktatora od listopada 1918 do stycznia 1919 r. i konstytucyjnego Naczelnika Państwa od lutego 1919 do grudnia $1922 \mathrm{r}$.

15 S. Skwarczyński, Przemiany duchowe..., s. 3.

16 W sprawie rozumienia i realizacji przez Piłsudskiego polskiej racji stanu do 1918 r. zob. J. Ga ul, Przez zaborcza. Austrię do niepodlegtej Polski. Militarny, polityczny i cywilizacyjny wymiar polskiej racji stanu 18671918, „Przegląd Wschodni” 2019, nr 58, s. 235-271.

17 Według G. Le B on a, op. cit., s. 14: „Znajomość psychiki tłumu stanowi obecnie umiejętności męża stanu, który nie pragnie już rządzić tłumem - bo to rzecz prawie niemożliwa - ale sam chce uniknąć przynajmniej ulegania tłumom”. „Dlatego wielcy mężowie stanu we wszystkich krajach i we wszystkich okresach, lącznie z najbardziej bezwzględnymi despotami, uważali wyobraźnię mas za podwalinę swej władzy. Nigdy nie próbowali pójść przeciw nim”. Ibidem, s. 36. W przeciwieństwie do innych polityków Piłsudski wyróżniał się krytycznym stosunkiem do społeczeństwa. J. G a u l, Czarno-żótty miraż..., passim. Komentując odczyt Marszałka Piłsudskiego wygłoszony 24 sierpnia 1923 r. w Wilnie, J. Gierowska-Kałłaur uważa, że Marszałek Piłsudski, który nie szczędził ostrej krytyki społeczeństwu polskiemu, w pewnych sytuacjach szyfrował świadomie przekazywane treści. „Był to wykład dla przyszłych pokoleń. Nie było jego zamiarem dawanie amunicji współczesnym wrogom. Był mężem stanu i umiał przewidzieć konsekwencje zbyt otwartej krytyki polskiego społeczeństwa. Jest ironią losu, że tylko nieliczni go, po dziś dzień, zrozumieli”. Jej zdaniem, realizując operację wyzwolenia Wilna, zwyciężył jako wojskowy i przegrał jako polityk. „Z kart wykładów wyziera dramatyczna postać, która przegrała przede wszystkim ze swoim własnym społeczeństwem". J. Gierowska-Kałłau r, Odczyt Marszatka Pitsudskiego wygtoszony 24 sierpnia 1923 roku w Wilnie, „Przegląd Wschodni” 1998, t. 5, z. 4, s. 770-776.

18 Przed wybuchem wojny Piłsudski nie schlebiał większości, stawał po stronie robotników, kobiet, mniejszości etnicznych. Nie uwodził tanimi hasłami. Nie krył, że wywalczenie niepodległości będzie wymagało ofiar. Dla szkolonych strzelców najwyższą nagrodą miała być wolna ojczyzna, ale droga do niej nie była usiana różami. Obiecywał im krew, pot i łzy, a owoców ostatecznego zwycięstwa miało doczekać niewielu. J. Ga ul, Czarno-żótty miraż..., s. 63-67. 


\section{Komendant i wódz (sierpień 1914-wrzesień 1916)}

Piłsudski przed wybuchem Wielkiej Wojny nakreślił cele wojskowe i polityczne, które miały być atutem w walce o niepodległą Polskę - budowę sił zbrojnych i utworzenie rządu narodowego. Możliwość konfliktu austriacko-rosyjskiego po aneksji Bośni i Hercegowiny przez Austro-Węgry w 1908 r. wymagała podjęcia kroków politycznych. Powołanie rządu narodowego okazało się niemożliwe. W listopadzie 1912 r. w Wiedniu powstała Komisja Tymczasowa Skonfederowanych Stronnictw Niepodległościowych, „aby umożliwić walkę czynną w Polsce zmierzającą do odzyskania wolności i niepodległości narodu polskiego"19. Piłsudski został mianowany komendantem sił wojskowych i podjął starania o przygotowanie Polaków do zbliżającego się konfliktu zbrojnego z udziałem państw zaborczych ${ }^{20}$.

Po wybuchu wojny Piłsudski wkroczył na czele strzelców z Galicji do Kongresówki. Występowanie w roli samodzielnego dowódcy i tworzenie Komisariatów Rządu Narodowego trwało tylko do 22 sierpnia 1914 r., gdyż zaniepokojone władze austro-węgierskie zlikwidowały akcję strzelecką. Piłsudski nie miał innego wyboru niż wstąpienie do Legionów Polskich. Stanął na czele 1 Pułku Piechoty i znalazł się w szeregach armii austro-węgierskiej ${ }^{21}$.

Znakomite wypełnianie funkcji dowódczych w oddziałach strzeleckich i w Legionach Polskich sprawiło, że Piłsudski stał się niekwestionowanym wodzem dla podwładnych ${ }^{22}$. Komendant swoje zadania traktował poważnie, poczuwał się do odpowiedzialności ${ }^{23} \mathrm{i}$ zmagał się z ciężarami pracy dowódcy, których nie rekompensowały laury sławy ${ }^{24}$. Piłsudski doczekał się pochwał ze strony cesarza Franciszka Józefa I, naczelnego wodza arcyksięcia Fryderyka, ministrów oraz generałów austro-węgierskich i w przeciągu kilku miesięcy z komendanta ochotniczego oddziału strzelców awansował na brygadiera Legionów Polskich ${ }^{25}$.

19 Galicyjska dziatalność wojskowa Pitsudskiego 1906-1914. Dokumenty, wybór i oprac. S. A r ski, J. C h u d ek, Warszawa 1967, s. 602-605.

20 A. Garlicki, Geneza legionów. Zarys dziejów Komisji Tymczasowej Skonfederowanych Stronnictw Niepodlegtościowych, Warszawa 1964, s. 76-77; i d e m, Józef Pitsudski..., s. 223-225; W. Su le ja, Józef Pitsudski, s. 86-112; J. Gaul, Czarno-żótty miraż..., s. 39-67.

21 J. Gaul, Czarno-żótty miraż..., s. 88-97.

22 W.Suleja,JózefPitsudski, s. 127, 131-132; M. Ja bło now ski, E. Ko ss ew sk a, Pitsudski na tamach prasy bytych wojskowych, [w:] Pitsudski na tamach i w opiniach prasy polskiej 1918-1939, red. M. Jab to n ow ski, E. Koss ewska, Warszawa 2005, s. 127-133.

23 Piłsudski akcentowal „prawdę o istocie dowodzenia, prawdę o duszy dowódcy, uginającej się pod ciężarem niebezpieczeństw, niepewności i sprzeczności. [...] Dowódca niesie prócz tego ciężar odpowiedzialności za swych podwładnych, a na policzku swoim czuć musi piekący wstyd upokorzenia, gdy mu praca dowodzenia się nie uda, a za niepowodzenie krwią płacą inni”. Id e m, Pisma zbiorowe, t. VIII, s. 168-169.

24 W. Ję d rzeje wi cz, J. Ci sek, Kalendarium życia Józefa Pitsudskiego 1867-1935, t. I, Kraków-Łomianki 2006, s. 388.

25 J. Gaul, Czarno-żótty miraż..., s. 98-133. 
Wojskowe walory Piłsudskiego docenili niektórzy politycy polscy. Zaczęto mówić o legendzie i „opromieniającej sławie”26. Dnia 21 grudnia 1914 r. w Wiedniu konserwatysta i prezes Naczelnego Komitetu Narodowego (NKN) Władysław Leopold Jaworski podkreślił, że „tym pierwszym, tym jedynym, który miał zdolność decyzji, zdolność ryzyka, nie dającego się odłączyć od wojny, byłeś Ty, Panie Brygadierze. Porwałeś za sobą społeczeństwo. [...] Wskutek tego Legiony mają wielorakie znaczenie: bronią honoru narodu polskiego"27. Jaworski miał jednak wątpliwości: „Zastanawiam się, co tkwi w tym człowieku. Nie wiem. Widzę kulturę, zdolności. Gdzie jest ten plus, który wysuwa ludzi na czoło? Nie wiem jeszcze. Może dojdę. Ma spokój, odwagę"28. Żołnierska postawa Komendanta zrobiła wrażenie na Janie Hupce, pośle do Sejmu Krajowego w Galicji. Na fali romantycznego nastroju widział w nim hetmana na miarę generała Jana Dąbrowskiego lub księcia Józefa Poniatowskiego ${ }^{29}$.

Stanowisko brygadiera w Legionach Polskich, mających status pospolitego ruszenia, nie było wysokie w armii austro-węgierskiej. Pomimo tego wiara i zapał kół wojskowych i pepeesowskich koncentrowała się na I Brygadzie i Józefie Piłsudskim, uznawanym za wodza i „Naczelnika narodowego”30. Piłsudski zdawał sobie sprawę z osiągniętej pozycji, lecz wiedział, że zawdzięczał ją postawie swoich żołnierzy ${ }^{31}$. Dnia 29 stycznia 1915 r. pisał z Kęt do Aleksandry Szczerbińskiej:

[...] sława zrobiona była rzetelną i ciężką psychicznie pracą, pełną nieraz ciężkich pełnych bólu i goryczy chwil, którem przeżywać musiał, kierując tak dziwaczną nawą jak mój oddział, po fluktach tak niepewnych i wariackich jak, nie powiem bój sam, lecz stosunków wojennych całego otoczenia wojennego do nas. [...] na 2-go mam festyn w Białej, tu jakieś deputacje i uroczystości, a na wszystkich muszę być z głupio-poważną miną jako bohater dnia, wysłuchiwać moc toastów, krzyków itd. No, przynajmniej mojej garstki nie wybijają i to wygrana dobra ${ }^{32}$.

Dla wielu ludzi sukcesy podobne do odnoszonych przez Komendanta mogłyby być pokusą do kontynuacji kariery w armii austro-węgierskiej i rezygnacji z ideałów niepod-

26 W pewnym stopniu Komendant tworzył swoją legendę, w czym wspomagali go dziennikarze, pisarze, artyści. W. Suleja, Józef Pitsudski, s. 127.

27 W. L. Jaw or ski, Diariusz 1914-1918, wybór i oprac. M. Czajk a, Warszawa 1997, s. 21-22; J. Hu pk a, Z czasów Wielkiej Wojny. Pamiętnik nie kombatanta, Niwiska 1936, s. 42-43; Pamiętnik Hermana Diamanda zebrany z wyjątków listów do żony, Kraków 1932, s. 130; W. Su le ja, Józef Pitsudski, s. 127-128.

28 W. L. Jaworski, Diariusz 1914-1918, s. 20; W. Su le ja, Józef Pitsudski, s. 127-129.

29 J. Hupka, Z czasów Wielkiej Wojny..., s. $42-43$.

30 G. Nowik, Odrodzenie Rzeczypospolitej..., s. 108-109.

31 J. Piłsud ski, Pisma zbiorowe, t. IV, s. 22; R. S ta r zy ń sk i, Cztery lata wojny w stużbie Komendanta. Przeżcia wojenne 1914-1918, Warszawa 2012, s. 85.

32 Wyjątki z listów Marszatka Józefa Pitsudskiego, „Niepodległość” 1948, t. 1, s. 11 . O „skromności, z jaką Ziuk dźwiga sławę, która go nie zmieniła pod żadnym względem" przekonywała także żona Maria Piłsudska. Pamiętnik Hermana Diamanda..., s. 132. 
ległościowych. Piłsudskiemu, „fanatycznemu polskiemu patriocie” (określenie szefa austro -węgierskiego wywiadu płk. Oskara Hranilovića), okruchy łaski spadające z c. i k. stołu nie mogły wystarczyć. Piłsudskiemu nie chodziło o awanse i medale dla żołnierzy, tylko o wpojenie im wartości, składających się na wysokie morale wojska. Jego interes osobisty znaczył niewiele w porównaniu z celem wyższym - budową armii polskiej ${ }^{33}$.

Szybkiej ścieżce awansu wojskowego Komendanta nie towarzyszyły nadzwyczajne osiągnięcia polityczne. Po wybuchu wojny realizacja planu utworzenia rządu narodowego napotykała trudności. Piłsudski utworzył jedynie fikcyjny Rząd Narodowy w Warszawie. Podejmowane później próby konsolidacji narodowej nie wykroczyły poza ugrupowania tworzące radykalny obóz niepodległościowy ${ }^{34}$. Działania Piłsudskiego zdeterminowane były szerszymi planami niż robienie kariery w c. i k. armii lub zabieganie o względy polityków i społeczeństwa polskiego oraz władz państw centralnych. Piłsudski zrozumiał, że walka o rząd narodowy i armię wymaga kroków bardziej radykalnych - licytacji wzwyż sprawy polskiej. Zakładał, że pozycja Polaków wobec monarchii wzrośnie dopiero po zajęciu Warszawy, a do Królestwa Polskiego wejść trzeba z „szerszą ideą" niż rozwiązanie austro-polskie ${ }^{35}$. Po uwolnieniu ziem polskich od jarzma rosyjskiego rola Legionów będzie skończona i dalsza walka z Rosją nie miała sensu ${ }^{36}$. Należało magazynować siły do kolejnego etapu walki, tym razem z państwami centralnymi, które zostaną w wojnie pokonane. Towarzyszyły temu dyrektywy polityczne w celu osobnej organizacji Królestwa, traktowanego na równi z Galicją, niezależnie od NKN i jego organów. Piłsudski wysunął żądania wojskowe - postawienie na czele Legionów „mnie czy kogo innego", byle z Legionów i przekazanie uzupełnień dla I Brygady ${ }^{37}$.

Kolejnym środkiem nacisku na władze państw centralnych po zajęciu Warszawy 5 sierpnia 1915 r. było wstrzymanie werbunku do Legionów, jeśli nie będzie politycznych i wojskowych koncesji. Piłsudski zapoznał ze swoimi planami współpracowników i grono polityków polskich. Na Stanisławie Thugucie, działaczu ludowym i żołnierzu I Brygady, zrobił wielkie wrażenie, jakkolwiek wydał mu się raczej „prorokiem niż wodzem”38. Oficjalnym politycznym programem minimum (maksymalnym było niepodległe państwo) Piłsudskiego w czasie wojny, o czym pisał w liście z 1 września 1915 r. do prezesa Jaworskiego, było połączenie Galicji i Królestwa w składzie monarchii austro-węgierskiej i to łączyło

33 W. Jęd rzejewicz, J. Cisek, Kalendarium życia..., t. I, s. 388.

34 J. Molen da, Pitsudczycy a narodowi demokraci 1908-1918, Warszawa 1980, s. 489-490; J. G a u l, Czarnożótty miraż..., passim.

35 W. L. Jaw or ski, Diariusz 1914-1918, s. 20; W. Su le ja, Józef Pitsudski, s. 127-129.

36 I. Bo er ner, Z pamiętnika, „Niepodległość” 1938, t. 17, s. 198; W. Ję d rzej ew ic z, J. Cis ek, Kalendarium życia..., t. I, s. 408.

37 J. Piłsudski, Korespondencja 1914-1917, oprac. S. Biegański, A. Suchcitz, Londyn 1984, s. 61-63; J. Paj ą k, O rząd i armię. Centralny Komitet Narodowy (1915-1917), Kielce 2003, s. 53-55; A. Ga rlicki, Józef Pitsudski.., s. 276.

38 S. Thugut t, Autobiografia, Warszawa 1984, s. 81. 
go z NKN. Współpraca z Austrią na dotychczasowych warunkach, bez rekompensaty za rekrutację przeprowadzoną na ziemiach zaboru rosyjskiego, nie dawała korzyści sprawie polskiej. Jeżeli dla jakichkolwiek powodów Austria chciała zużytkować materiał ludzki lub odwołać się do opinii w Królestwie Polskim, to jedynym środkiem była „metoda rekompensatowa”. W kwestii Legionów kompromisowym rozwiązaniem byłoby powierzenie mu na pewien czas komendy nad Legionami ${ }^{39}$.

Politycy polscy mieli problemy z oceną postępowania Piłsudskiego. Nawet tak wytrawny polityk jak W. L. Jaworski uznał scenariusz przedstawiony w Warszawie za porażkę ${ }^{40}$. W maju 1916 r. oskarżył go ponownie, że uwierzył w swoją wielkość, a był tylko brygadierem austriackim i na dodatek nie poszło za nim społeczeństwo ${ }^{41}$. Jaworski uważał, że Piłsudski „w gruncie rzeczy jest bezradny. Straszy. Sam ugina się pod opinią wielkości, którą go otoczyli. Może w nią uwierzył! Nie, nie, to nie jest «zbawca»" "2. Jan Hupka był bardziej wyrozumiały. Uważał, że Piłsudski doznał wielu przykrości z powodu ,austriackiej głupoty i złośliwości”. Nie chciano go zrobić wodzem Legionów, bo mu nie ufano i narzucono mu generała, „co mu pod żadnym względem do pięt nie dorósł”ł3.

Nieustępliwa postawa Piłsudskiego stawia pytanie o jego zdolność do kompromisu. W polityce wywołują one kontrowersje, chociaż są dopuszczalne $e^{44}$. Pole manewru zawęża się w przypadku męża stanu. Komendant był gotów do zawarcia w połowie 1916 r. porozumienia z AOK, ale z zastrzeżeniem: „dla żadnych wątpliwych korzyści, dla żadnych obietnic

39 J. Piłsudski, Korespondencja 1914-1917, s. 75-83; I. Daszyński, Pamiętniki, t. II, Warszawa 1956, s. 214-217; S. Skw a rc zy ńs ki, Licytacja sprawy polskiej wzwyż. Podstawy i metody politycznej dziatalności Józefa Pitsudskiego w okresie pierwszej wojny światowej, „Niepodległość” 1972, t. 8, s. 17-18; A. Ga rlicki, Uźródet obozu belwederskiego, Warszawa 1979, s. 276; i d e m, Józef Pitsudski, s. 279-281; J. S u le ja, Orientacja austro-polska w latach I wojny światowej (do aktu 5 listopada 1916 roku), Wrocław 1992, s. 152-165, Acta Universitatis Wratislaviensis, nr 1421, Historia, t. 103; i d e m, Józef Pitsudski, s. 143-145; R. Św ię tek, Lodowa ściana. Sekrety polityki Józefa Pitsudskiego 1904-1918, Kraków 1998, s. 795-796; W. Ję d r zejewicz, J. Cis ek, Kalendarium życia..., t. I, s. 430-431.

40 W. L. Jaw or ski, Diariusz 1914-1918, s. 55-56.

41 O niechęci do Piłsudskiego pisał narodowy demokrata Juliusz Zdanowski. Dziennik Juliusza Zdanowskiego, t. II: 15 X 1918-23 VI 1919, przedmowa i oprac. J. Fa r yś [et al.], Szczecin 2014, s. 213-214.

42 W. L. Jaw orski, Diariusz 1914-1918, s. 100-102. Piłsudski miał stosunek krytyczny do swojej „wielkości”, o czym pisał 24 grudnia 1914 r. do Aleksandry Szczerbińskiej. Wyjątki z listów..., s. 11.

43 Chodziło o gen. Karola Trzaskę-Durskiego. J. Hupka, Z czasów Wielkiej Wojny..., s. 119. S. Thugutt, widząc Piłsudskiego na początku lipca 1916 r. podczas bitwy pod Kostiuchnówką, jak spokojnym i władczym głosem wydawał rozkazy, napisał: „Tak, tutaj był to już nie prorok, lecz wódz w całym tego słowa znaczeniu". I d e m, Autobiografia, s. 88.

44 Komendant nie potępiał kompromisów i zawierał je, jak twierdził: ,jak długo tylko było można, jak długo oczekiwałem korzyści lub dopóki mogłem przerobić to, co wyrwałem na bene narodowe". Przelewanie krwi legionistów nie poszło na marne, gdyż chodziło o poświęcenie dla zmartwychwstania Polski. W. B a ra now ski, Rozmowy z Pitsudskim 1916-1931, Warszawa 1990, s. 25-26. W czasach niepodległości kompromis uważał za „istotę demokratyzmu”, gdy jego konieczność „urasta w zasadę szanowania innych, jako współobywateli". J. Piłsu d ski, Pisma zbiorowe, t. V, s. 295. 
kuszących od naszego honoru wojskowego, od naszej cnoty wojskowej nie ustąpię. Do końca dobrego czy złego donieść tę cnotę bez plamy, niczego z niej nie uronić - to mój program minimalny” ${ }^{5}$. Nie mniej ważna była świadomość wyniesienia go „na wodza polskiego w tej wojnie" przez aktywną część narodu, w tym także z Legionów. Tak wysoka symboliczna ranga powodowała, że ramy wojskowe okazały się za ciasne i dochodziło do konfliktów z c. i k. władzami. Co gorsza, twierdził: „nie potrafię już bez realnych zmian utrzymać swoją osobą morale wojska na dawnej wysokości, więc muszę być przygotowany na obniżenie wartości i tych czynów wojennych, które wojsko czyni, a to znowu nie odpowiada ani memu sumieniu, ani honorowi człowieka, który reprezentuje sobą wojenny czyn Polski”6. Jak wyjaśnił 12 sierpnia 1916 r. Waleremu Sławkowi, postanowił zaryzykować, „nie broniąc absolutnie niczego $z$ dotychczasowej postawy i wysuwając na plan pierwszy jako ofiarę samego siebie" ${ }^{37}$. Dla Piłsudskiego istotna była sprawa lojalności. Dnia 25 lipca 1916 r. pisał do Ignacego Daszyńnkiego, że jest zdecydowany ustąpić, gdyż nie mógł odpowiadać za pracę przed Polską i żołnierzami, bo przestał wierzyć, jak pisał: „czy tak pracując daję cokolwiek wspólnemu interesowi Austrii i Polski. Zmuszony jestem do nielojalności albo względem jednej, albo względem drugiej, bo tu ciągła i wyraźna sprzeczność występuje. Nie umiem przekraczać za dużo granic lojalności i w tej rozterce sumienia trwać nie mogę"48.

Wykładnię pozycji wodza i autorytetu wyjaśnił w liście z 23 sierpnia 1916 r. do szefa wywiadu płk. Hranilovića. Poczuwał się do odpowiedzialności przed skłonną do ryzyka częścią społeczeństwa, a nie mógł jej złożyć, dopóki nie było w narodzie zorganizowanego autorytetu moralnego, umiejącego wymusić posłuch. Nie mieścił się w formie przydzielonej mu w Legionach i uważał za moralny obowiązek podanie się do dymisji. Piłsudski prosił Hranilovića, aby zrozumiał położenie człowieka, „który, z jednej strony ma odpowiedzialność, z drugiej żadnej możliwości nie ma, aby sobie ułatwić niesienie tej odpowiedzialności” ${ }^{\circ}$. O determinacji Piłsudskiego świadczył fakt, że był zdecydowany „nawet przy propozycji objęcia komendy uczynić ją zależną od niektórych warunków" 50 . Władze austriackie nie przyjęły argumentacji Komendanta i w piśmie z 29 lipca 1916 r. podpisanym przez arcyksięcia Fryderyka poinformowano go o zwolnieniu z Legionów ${ }^{51}$.

45 B. Wieniawa-Długoszowski, Wymarsz i inne wspomnienia, [Łomianki] 2012, s. 85-87.

46 J. Piłsudski, Korespondencja 1914-1917, s. 210.

47 Ibidem, s. 207.

48 I. Daszyński, Pamiętniki, t. II, s. 231.

49 J. Piłsudski, Korespondencja 1914-1917, s. 211-215; K. Świtalski, Diariusz 1916-1917, cz. 2, „Niepodległość" 1996, t. 48, s. 34-35; W. Su le ja, Orientacja austro-polska..., s. 277.

50 List do W. Sławka z 23 sierpnia 1916. J. Piłsudski, Korespondencja 1914-1917, s. 216. Uzasadnienie decyzji o dymisji w liście do W. L. Jaworskiego. Ibidem, s. 222.

51 Österreichisches Staatsarchiv (ÖStA) / Haus-, Hof- und Staatsarchiv (HHStA), Ministerium des Äussern (M.d.Ä.), Politisches Archiv (PA) I, kart. 901, Krieg 8 a, k. 58, K.u.k. AOK, K. Nr. 17849, Leg. ObstBrig. v. Piłsudski - Entlassung aus den Poln. Leg., Streng geheim, durch Kurier, 26.9.1916; ibidem, Kriegs- 
Dymisja Piłsudskiego spotkała się z różną oceną. Prezes NKN Jaworski uważał, że opuszczenie Legionów oznaczało jego klęskę ${ }^{52}$. W kręgach niepodległościowych wywołała wstrząs, a w Legionach dymisje składane przez oficerów i żołnierzy ${ }^{53}$. Zaniepokojony Jaworski, który niedawno widział w Piłsudskim przegranego człowieka, wystosował 5 października 1916 r. list otwarty. Przyznał proroczo, że „imię Piłsudskiego będzie nieodłącznym od Legionów i Wojska Polskiego". Oczekiwał uspokojenia nastrojów i wezwał do wytrwania w służbie, ponieważ znał decyzję Austrii i Niemiec z 11-12 sierpnia 1916 r. o ogłoszeniu samodzielnego państwa polskiego ${ }^{54}$. Piłsudski odpowiedział Jaworskiemu 6 października 1916 r. Pocieszając się, że jest możliwa współpraca i zrozumienie różnych grup, a w krytycznych chwilach „zorganizowanie woli narodu” (z tym były problemy nawet w listopadzie 1918 r. $)^{55}$, przypomniał, że jego celem w sierpniu 1914 r. było minimalne zadanie - wskrzeszenie tradycji orężnej Rzeczypospolitej. Miał powody, aby dumnie oświadczyć: „Gdybym mógł swych młodych żołnierzy, śniących w grobie o Polsce, zapytać o zdanie szczere - a umarli i umierający nie kłamią - powiedzieliby wraz ze mną, ich wodzem, że nie żałujemy ani krwi, ani ofiar, gdy ten sen i marzenie długich lat się ziściły. Żołnierz polski, własnymi polskimi siłami stworzony, dał swej ojczyźnie nową wartość, której bez niego nie posiadała" ${ }^{\prime 6}$.

archiv (KA), Kriegsministerium, Präs. 1916, 72-48/4. Präs. Nr. 26543, Polnische Legionen betreffend, 9.10.1916; ibidem, sygn. 72-48/3. K.u.k. Kriegsministerium, Präs. Nr. 26542, Poln. Leg. Brig. v. Piłsudski Entlassung aus der polnischen Legion, 9.10.1916; A. Hausner, Die Polenpolitik der Mittelmächte und die österreichisch-ungarisch Militärverwaltung in Polen während des Weltkrieges, Wien 1935, s. 78-80, 108; W. L. Ja wo r ski, Diariusz 1914-1918, s. 130; J. Holze r, J. Molend a, Polska w pierwszej wojnie światowej, Warszawa 1973, s. 168; M. Wr zo se k, Polski czyn zbrojny..., s. 249; W. Su l e ja, Józef Pitsudski, s. 162; A. Pe thö, Agenten für den Doppeladler. Österreich-Ungarns Geheimer Dienst im Weltkrieg, Graz-Stuttgard 1998, s. 311; M. Rau chenstein er, Der Erste Weltkrieg und das Ende der Habsburgermonarchie 1914-1918, Wien-Köln-Weimar 2013, s. 758; J. Ga u l, Na tajnym froncie. Dziatalność wywiadowczo-informacyjna obozu niepodlegtościowego w latach 1914-1918, Warszawa 2001, s. 318; id e m, Czarno-żótty miraż..., s. 208-238.

52 W. L. Jaworski, Diariusz 1914-1918, s. 133, 138-141.

53 Centralne Archiwum Wojskowe (CAW), Legiony Polskie (LP) i Polski Korpus Posiłkowy (PKP), sygn. 120.1.1. Gstb Nr. 67, 30.7.1916; Archiwum Akt Nowych (AAN), Kolekcja akt różnej proweniencji, I/82, k. 200: K. Świtalski - materiały, t. 10; F. D u bi el, Pamiętnik wojenny 1916-1917, [w:] J. Sk rzy pczak, Idea i czyn. Drogi mielczan do niepodlegtości 1907-1918, Mielec 2003, s. 217; R. Starzyński, Cztery lata..., s. 324-326; J. G a ul, Na tajnym froncie..., s. 267.

54 J. Piłsudski, Pisma zbiorowe, t. IV, s. 82-83; J. Hu pka, Z czasów Wielkiej Wojny..., s. 243; W. Suleja, Orientacja austro-polska..., s. 295-296; W. Ję d r zej ew icz, J. Cis ek, Kalendarium życia..., t. II, s. 9.

55 J. Piłsudski, Pisma zbiorowe, t. VI, s. 28

56 Ibidem, t. IV, s. 83-84; zob. J. Hu pk a, Z czasów Wielkiej Wojny..., s. 243; W. Suleja, Orientacja austro-polska..., s. 296; J. G a u l, Czarno-żótty miraż..., s. 228-229. 


\section{„Dyktator moralny” ( październik 1916-październik 1918)}

W czasach kryzysów, a do takich należała Wielka Wojna, rodziło się wśród ludzi zapotrzebowanie na charyzmatycznych przywódców, którzy potrafili wzbudzić zaufanie i swoim autorytetem oraz decyzjami porwać ich do czynu. Wyrazem odpowiedzi społeczeństwa na „apel bohatera” (Henri Bergson) była popularność gen. Philippe’a Pétaina i premiera Georges’a Clemenceau w społeczeństwie francuskim ${ }^{57} . \mathrm{Z}$ podobną reakcją wielu Polaków spotkała się działalność Piłsudskiego. Reprezentowane wartości spowodowały, że Komendant, który po zwolnieniu z Legionów we wrześniu 1916 r. przestał być dowódcą z formalnego punktu widzenia, nadal był przywódcą moralnym swoich żołnierzy. W memoriale z połowy $1917 \mathrm{r}$. internowani podkomendni tłumaczyli tego przyczynę:

Wobec tego Legiony, które przecież zostały powołane do życia nie przez obowiązek służby wojskowej, lecz przez pewne przekonania polityczne uczestników, musiały iść same swoją drogą, a swego Komendanta uważać za moralnego dyktatora narodu. [...] Wszak niepodobieństwem dla nas było przyznanie kwalifikacji moralnego dyktatora Polski pierwszemu lepszemu generałowi lub pułkownikowi, którego rząd austriacki na czele Legionów postawił. Dlatego uważaliśmy za dyktatora Piłsudskiego, którego potężna indywidualność i bezwzględna czystość dawały nam rękojmię, że rząd dusz w dobrych znajduje się rękach ${ }^{58}$.

Jesienią 1916 r. w artykułach prasowych dowodzono, że Piłsudski w swoich dążeniach do utworzenia armii polskiej wzniósł się ponad partie i należał do całego narodu ${ }^{59}$. Na łamach warszawskich „Notatek Politycznych” i „Kuriera Lwowskiego” ubolewano, że w społeczeństwie miał wielu wrogów, którzy zarzucali mu rewolucyjną przeszłość, ale to ona dawała mu prawo wystąpienia jako przywódca przeciwko największemu wrogowi - Rosji. Duchowy niewolnik nie mógł bowiem dowodzić armią wyzwoleńczą ${ }^{60}$. Lwowska „Gazeta Wieczorna” zarzuciła PPS nadużywanie nazwiska Piłsudskiego w agitacyjnej pracy w Królestwie Polskim, gdyż należał on do całego narodu i nie wolno było żadnej partii używać

57 J.-B. D u ro selle, Wielka wojna Francuzów 1914-1918, thum. A. Ci as tek, Warszawa 2006, s. 182, 283.

58 ÖStA / KA, Nachlass (NL), Nachlass Mieczysław Szwestka B/89, k. 209, Memoriał, Głos odchodzących żołnierzy polskich do społeczeństwa [bez daty i podpisu]. W. Suleja wskazuje, że uwielbienie legionistów nie miało charakteru bezrefleksyjnego i nie skłaniało ich do ślepego wykonywania rozkazów. Id e m, Józef Pitsudski, s. 131-132; J. G a ul, Czarno-żótty miraż..., s. 240-244,

59 A. Piłsudska, Wspomnienia, Warszawa 1989, s. 170; J. Z. Pająk, O rząd i armię..., s. 171.

60 Pitsudski, „Kurier Lwowski”, nr 505, 9.10.1916 - ÖStA/KA, Kriegsüberwachungsamt (KÜA), kart. 160, KÜA Nr. 86069, 20.10.1916; K.u.k. Haupt K. Stelle Lemberg, K. Nr. 10211, 18.10.1916. Lemberger Pressebericht vom 1. Oktober bis. 16. Oktober 1916; J. G a u l, Czarno-żótty miraż..., s. 243. 
jego osoby jako szyldu dla swoich akcji politycznych ${ }^{61}$. W podobnym duchu Stronnictwo Pracy Narodowej w Warszawie pisało pod koniec 1916 r.: „Radykalizmu i socjalizmu nie obawiają się umiarkowani politycy polscy, wszyscy bowiem wiedzą, iż Piłsudski nie jest dzisiaj człowiekiem żadnej partii, żadnej doktryny, ale cały oddał się pracy wskrzeszenia państwa polskiego i jako taki do wszystkich należy"². Podobnie myśleli żołnierze Piłsudskiego: „Idziemy za nim dlatego, że w ogóle idziemy za czynem polskim, że on jest twórcą armii polskiej, której my jesteśmy żołnierzami. [...] Legiony były czynem samodzielnym nie jakiegoś rządu polskiego, ani jakichś partii politycznych, ale garstki ludzi, którzy na wezwanie twórcy ideologii polskiego czynu zbrojnego, Piłsudskiego, stanęli do szeregu" ${ }^{3}$.

Zdaniem Hupki Piłsudski był popularny nie tylko w kołach młodzieży, robotniczych i legionowych, lecz miał „wprost napoleońską zdolność fanatyzowania dla siebie ludzi. Znam bowiem ludzi starszych i bardzo inteligentnych, którzy na dźwięk jego nazwiska popadają w ekstazę i oczy stawiają w słup" ${ }^{64}$. Podczas wizyty Piłsudskiego w Lublinie pisarka Maria Dąbrowska zanotowała 28 listopada 1916 r. niezwykłą aurę: „Patrząc na niego i słuchając, myślałam, że nie jest to mąż stanu, ale poeta, romantyk i aktor, który swą wizję artystyczną świata rzucił na szalę wypadków" ${ }^{65}$. Warto przywołać uwagę Ernsta Jüngera o różnicach między mężem stanu a poetą: „Mąż stanu cieszy się większą realną władzą niż poeta, którego dzieło z kolei znacznie góruje na dziełem pierwszego siłą ducha, a przeto i trwałości”"66. Piłsudski był miłośnikiem poezji Słowackiego, którego wiersze towarzyszyły mu w życiu, a po śmierci motto z Beniowskiego zostało wyryte na nagrobku, na wyraźne jego życzenie w testamencie ${ }^{67}$.

Dowodem wojskowych umiejętności Polaków stały się Legiony, a wyrazicielem tej siły Piłsudski. Spory wywoływała sprawa zdolności politycznych społeczeństwa i jego przywództwa. Do roli tej pretendował Piłsudski, który uważał latem 1916 r. Legiony za kartę zgraną i alternatywę widział w działaniach politycznych. Miał świadomość ryzyka, gdyż w sferze „polityki i wartości czysto politycznych w Królestwie” jego nazwisko było jednym z wielu, a nie ,jedynym, jak to jest w wojskowości polskiej”68.

${ }_{61}$ Wegen Pitsudski, „Gazeta Wieczorna”, nr 3283, 12.12 .1916 - ÖStA/KA, KÜA, kart. 170, KÜA Nr. 91620 , 16.12.1916; K.u.k. Haupt K. Stelle Lemberg, K. Nr. 10928, 14.12.1916. Lemberger Pressebericht vom 9. Dezember bis. 12. Dezember 1916; J. G a u l, Czarno-żótty miraż..., s. 242-243.

62 Cyt. za: J.Z.Pająk, O rząd i armię..., s. 171.

63 ÖStA/KA, NL, Nachlass Mieczysław Szwestka B/89, k. 209; J. Ga ul, Czarno-żótty miraż..., s. 243-244.

64 J. Hupka, Z czasów Wielkiej Wojny..., s. 255-256.

65 M. Dąbrowska, Dzienniki 1914-1925, t. I, Warszawa 1998, s. 85; W. Ję d r ze je wicz, J. Cis ek, Kalendarium życia..., t. II, s. 27-28; W. Su le ja, Józef Pitsudski, s. 209-210.

66 E. Jünger przestrzegał, że „mąż stanu nie powinien kierować się ideałami poety ani myśliciela, zwłaszcza w trakcie burzliwych wydarzeń, pomijając, że obaj są istotni raczej dla przyszłego niż aktualnego świata”. Id e m, Robotnik, tłum. W. Kun i cki, Warszawa 2017, s. 309, 312

67 W. Jęd rzejewicz, J. Cis ek, Kalendarium życia..., t. IV, s. 410.

68 J. Piłsudski, Korespondencja 1914-1917, s. 156. W rezultacie Piłsudski miał licznych przeciwników, 
Ogłoszenie aktu 5 listopada 1916 r. oznaczało cezurę w sprawie polskiej. Trudno było sobie wyobrazić samodzielne Królestwo Polskie bez rządu. Dnia 6 listopada Piłsudski oświadczył rektorowi Uniwersytetu Warszawskiego Józefowi Brudzińskiemu: „pomimo, że się sam dla wielu stałem takim surogatem przedstawicielstwa polskiej władzy - tak samo, jak inni moi koledzy tęsknię do istnienia formy, w którą się normalnie wylewa ojczyzna żołnierza - do rządu, który żołnierza reprezentuje na zewnątrz, który z niego wszelkie troski polityczne zdejmuje i daje poczucie zrozumiałe celu, dla którego krew się daje" ${ }^{\text {. }}$. Postulat ten zgłaszał wielokrotnie pod adresem c. i k. Naczelnej Komendy Armii, której tłumaczył, że „pozostawanie w szeregach obcej - niepolskiej - armii bez wyraźnego nakazu własnej polskiej władzy politycznej jest tak ciężkim i trudnym do zniesienia, że z każdym dniem staje się to bardziej niemożliwym dla ludzi z zaboru rosyjskiego"70.

Surogatem władzy polskiej została TRS. Lewica niepodległościowa domagała się powołania do niej Piłsudskiego ${ }^{71}$. Jego kandydatura wzbudziła jednak wątpliwości. Hupka obawiał się, że Piłsudski zawładnie Radą Stanu: „Będzie to dobrze, o ile Piłsudski swemu socjalistycznemu otoczeniu nie da na siebie wpływać" ${ }^{72}$. Podobne zastrzeżenia miał Stanisław Kot w związku ze „znanym niewyrobieniem Królewiaków”73. Prezes Jaworski uważał, że Brygadier „przegrał przez brak cierpliwości. Nie wytrwał. Dwa razy zrobił decydujące pociągnięcia i oba razy spudłował: po uwolnieniu Warszawy chciał wstrzymać werbunek, a po swojej dymisji rozbić Legiony". Wykluczył wpuszczenie go z powrotem do wojska, bo by je zniszczył, tak jak Legiony. Dopuszczał tolerowanie go na gruncie politycznym, mając nadzieję, że w TRS „będzie stanowił opozycję i zużyje się, jak się w polityce zużywają"744.

Ocena kandydatury Piłsudskiego przez przedstawicieli państw centralnych pełna była sprzeczności. Oprócz starań o wyeliminowanie go z gry politycznej o sprawę polską ${ }^{75}$

jednym z nich był Zdanowski, który zapisał o nim 18 grudnia 1916 r. pogardliwe uwagi. Dziennik Juliusza Zdanowskiego, s. 302.

69 J. Piłsudski, Pisma zbiorowe, t. IV, s. 88-89.

70 Ibidem. Dnia 16 marca 1917 r. Piłsudski oświadczył, że zazdrościł wojskom państw centralnych, „że mieli za sobą wolę narodu swego, która im posłuszeństwo nakazuje, że mieli rząd zorganizowany, który dumę żołnierzy stanowi, który dla niego samego tę ojczyznę reprezentuje". Ibidem, s. 110-114; A. Piłsu dska, Wspomnienia, s. 163; M. Pruszyńsk i, Tajemnica Pitsudskiego, Warszawa 1997, s. 70.

71 A. Hausner, Die Polenpolitik der Mittelmächte..., s. 107-108; J. Rzep ecki, O Wtadystawie Sikorskim w Legionach. Zakończenie, „Wojskowy Przegląd Historyczny” 1966, t. 11, z. 1, s. 228; J. Paje wski, Odbudowa państwa polskiego..., s. 140; R. Św ięt ek, Lodowa ściana..., s. 822; J. G a u l, Czarno-żótty miraż..., s. 246.

72 J. Hupka, Z czasów Wielkiej Wojny..., s. 255-256.

73 W. L. Jaworski, Diariusz 1914-1918, s. 146.

74 Ibidem, s. 145-147; J. Ga ul, Czarno-żótty miraż..., s. 246-247.

75 M. Wrzosek, Dążenia austriackich i niemieckich czynników wojskowych do wyeliminowania Józefa Pitsudskiego z gry politycznej o sprawe polska podczas I wojny światowej (czerwiec 1915-lipiec 1917), [w:] Lata Wielkiej Wojny. Dojrzewanie do niepodlegtości 1914-1918, red. D. Grinberg, J. S no pko, G. Zackiewicz, Białystok 2007, s. 259-278; J. G a u l, Czarno-zótty miraż..., passim. 
równocześnie rozlegały się głosy bardziej trzeźwe. Delegaci austro-węgierscy w Królestwie Polskim twierdzili zgodnie, że utworzenie wojska polskiego bez współdziałania Piłsudskiego było niemożliwe. Dnia 4 grudnia 1916 r. delegat MSZ przy AOK Friedrich Wiesner odrzucił argumentację, że Piłsudski w TRS byłby niebezpieczniejszy niż poza nią. Nawet gdyby sprzeciwił się powołaniu armii, lepszym rozwiązaniem byłoby pozwolenie na jego opozycję w ramach TRS niż narażanie się na agitację poza nią. Piłsudski zasiadałby w niej jako członek odpowiedzialny przed narodem, jego poglądy musiałyby podlegać zmianom pod naciskiem różnych wpływów politycznych ${ }^{76}$. Podobnie stanowisko zajął przedstawiciel austro-węgierskiego MSZ w Warszawie Leopold Andrian, podkreślający konieczność posiadania w TRS przynajmniej odpowiedniej reprezentacji lewicy ${ }^{77}$.

Szef Sztabu Generalnego gen. Franz Conrad von Hötzendorf w nocie z 30 listopada do Istvána Buriána uważał, że w kwestii polskiej nie stać było monarchii na zwłokę. Kluczowe było wykorzystanie w państwie polskim Piłsudskiego, popularnego w szerokich kręgach i wskutek utworzenia POW dysponującego siłą wojskową. Utorowanie mu drogi do Rady Stanu mogło mieć znaczący wpływ na tworzenie wojska i przebieg werbunku. Conrad przeciwwagę dla Piłsudskiego widział w królu lub regencie, który skupi wokół siebie elementy konserwatywne i poskromi nieograniczone aspiracje Brygadiera ${ }^{78}$. Conrad zmieniał kilkakrotnie stanowisko, w końcu uległ argumentacji Buriána i poparł kandydaturę Piłsudskiego do TRS ${ }^{79}$.

Piłsudski szedł do Rady Stanu gotów na kompromis, tym razem z Niemcami, ale na jasnych warunkach: „Wojsko i werbunek choćby jak najszerszy, ale wojsko i rząd polski, któremu żołnierz nasz będzie podległy" ${ }^{80}$. Z Austrią chciał rozmawiać o przekazaniu Legionów jako podstawowych formacji armii polskiej i o uregulowaniu kwestii POW. Piłsudski nie spodziewał się wiele po TRS, obciążonej grzechem „niekompletności” z punktu widzenia narodowego, gdyż jego wysiłki rozszerzenia bazy politycznej i wciągnięcia do jej składu przedstawicieli Koła Międzypartyjnego nie powiodły się. Tak jak NKN obawiał się gniewu Wiednia, tak narodowi demokraci, jego zdaniem, bali się niezadowolenia ententy ${ }^{81}$.

76 ÖStA/HHStA, M.d.Ä. PA I, kart. 1016, Krieg 56 b/2, k. 44-46, Der Vertreter des k.u.k. M.d.Ä. beim k.u.k. AOK, Teschen, 4.12.1916; J. Molen d a, Pitsudczycy..., s. 364; J. Ko ch a n ow sk i, Powotanie Józefa Pitsudskiego do Tymczasowej Rady Stanu w świetle korespondencji wtadz austriackich (na marginesie artykutu Ryszarda Świętka, Polityka Józefa Pitsudskiego wobec aktu 5 listopada 1916, „Przegląd Historyczny”, t. 77, 1988, z. 1, s. 71-95), „Przegląd Historyczny” 1988, t. 79, z. 3, s. 534-535; J. G a u l, Czarno-żótty miraż..., s. 253.

77 J. Ko ch a now ski, Powotanie Józefa Pitsudskiego..., s. 535; J. Ga ul, Czarno-żótty miraż..., s. 253.

78 ÖStA/HHStA, M.d.Ä. PA I, kart. 1017, Krieg 56 b, k. 34-39. K.u.k. Chef des Generalstabes, Op. Geh. Nr. 184/XXXII, Polnische Königsfrage, Wien, 30.11.1916; ibidem, KA, NL, Nachlass Paić B/1438, 33: J. v. Paić, Das Austropolnische Problem im Weltkrieg, s. 94-95; J. Gaul, Czarno-żótty miraż..., s. $258-259$.

79 J. Gaul, Czarno-żótty miraż..., s. 245-261.

80 W. Baranowski, Rozmowy $z$ Pitsudskim..., s. 24-26.

81 Ibidem, s. 25. 
Po wejściu Piłsudskiego do TRS przeciwnicy pocieszali się, że jego prestiż maleje ${ }^{82}$ i oczekiwali na ustąpienie ${ }^{83}$. Prezes Jaworski twierdził, że Piłsudski pozostanie, „ale cała jego klientela będzie w opozycji przeciwko Radzie. Powtórzy się historia z NKN, wedle maksymy, że popularność można uzyskać i utrzymać tylko przez opanowanie" ${ }^{\text {"4 }}$. Liczył na zużycie się Piłsudskiego, który wkrótce stanie się „zgraną sztuką" ${ }^{85}$. Wbrew radom Ernsta Jüngera, że „żywiołem polityka jest aktualność. Nawet gdy zwleka, oczekuje stosownej chwili. Na tym polega jego siła, ale także ograniczenie, ponieważ o wartości jego dzieła, państwa, rozstrzyga wyłącznie sukces"86, Piłsudski ustąpił 2 lipca 1917 r. z TRS. Podczas posiedzenia wysunął poważne zarzuty przeciw c. i k. władzom, twierdząc, że Legiony, włączone do armii austriackiej, nie miały żadnego „politycznego wykładnika polskiego". Za katastrofalną uznał nieufność polityczną władz monarchii habsburskiej wobec samodzielnych wysiłków militarnych społeczeństwa polskiego, znajdującą wyraz w „opiece policyjnej austriackiej nad wojskiem polskim”. Uznał, że „jedyną służbą, jaką może jeszcze okazać braciom w wojsku polskim, ostatecznym ostrzeżeniem tych, których ostrzec należy, jest jego podanie się do dymisji”" ${ }^{\text {"7 }}$.

Ustąpienie Piłsudskiego z TRS starały się wykorzystać państwa centralne. W raporcie z lipca 1917 r. Oddziału Informacyjnego Generalnego Gubernatorstwa Wojskowego w Lublinie znalazła się insynuacja, że Piłsudski i lewica zamierzali odejść od polityki opierania się na państwach centralnych i nawiązać kontakty z Rosją, o czym miał świadczyć brak dementi ze strony Brygadiera na wiadomość o wyborze na honorowego przywódcę kongresu w Petersburgu. Austriacy ocenili błędnie, że Piłsudski stracił na swojej popularności z powodu mało zrozumiałego postępowania i spadł z piedestału bohatera narodowego, na który postawiły go historia i jego czyny na początku wojny, do poziomu socjalistycznego działacza. Służby informacyjne dostrzegały bezzasadnie szansę na przyklejenie Piłsudskiemu etykiety przywódcy partyjnego ${ }^{88}$.

82 G. Le Bon (op. cit., s. 64-66) utrzymywał, że na prestiż składa się wiele elementów, nie tylko powodzenie, ale także osobiste zalety lub sława wojenna.

83 S. Ko morn ick i, Fragmenty pamiętnika Stanistawa Downarowicza, „Zeszyty Historyczne” 1975, z. 33, s. $97-104$.

84 W. L. Jaworski, Diariusz 1914-1918, s. 154.

85 „Ein abgespieltes Repertoirestück”. W. L. Jaw or ski, Diariusz 1914-1918, s. 158.

86 E. Jünger, Robotnik, s. 309.

87 J. Piłsudski, Pisma zbiorowe, t. IV, s. 201-204; M. Wr zosek, Dążenia austriackich..., s. 274; J. Gaul, Czarno-żótty miraż..., s. 287.

88 Archiwum Główne Akt Dawnych (AGAD), Militärgeneralgouvernement (MGG) in Lublin, sygn. 2156. K.u.k. MGG in Lublin, Nachrichtenabteilung, NA Nr. 27799 res 1917, Politischer Bericht, Lublin, 29.7.1917; Materiaty archiwalne, t. I, s. 72-89; L. Grosfeld, Polityka państw centralnych wobec sprawy polskiej w latach pierwszej wojny światowej, Warszawa 1962, s. 222-224, 226-227. Zob. ÖStA/HHStA, M.d.Ä. PA I, kart. 1011, Krieg 56a/1,2. Der Vertreter des k. und k. M.d.Ä. beim k. und k. MGG in Polen, Nr. 137 B, Politischer Monatsbericht der Nachrichtenabteilung des MGG Wien, Lublin, 8.12.1917; R. Świętek, Lodowa ściana..., s. 840; J. G a ul, Czarno-żótty miraż..., s. 298-299. 
Niemcy mieli dość Piłsudskiego, bo przeszkadzał im w realizacji planu politycznego związania „niepodległego” państwa polskiego z Rzeszą - i wojskowego - budowy Polskiej Siły Zbrojnej. Ostatnią kroplą był kryzys przysięgowy w Legionach w lipcu 1917 r., za który nie bez racji obarczono odpowiedzialnością Piłsudskiego. Wyeliminowanie go z życia publicznego miał ułatwić fakt, że - zdaniem władz niemieckich i wielu środowisk polskich - Piłsudski był politykiem przegranym. Aresztowanie w nocy 21/22 lipca $1917 \mathrm{r}$. w Warszawie i późniejsze internowanie w Magdeburgu miało raz na zawsze uwolnić władze okupacyjne od kłopotu i ułatwić usunięcie Komendanta ze świadomości Polaków ${ }^{89}$.

Piłsudski przegrał jako polityk, wygrał za to jako mąż stanu. Zorganizowanie odmowy złożenia przysięgi było wyrazem sprzeciwu i manifestacją trwania na gruncie najwyższych wartości. Udowodnit, że nie zawierał kompromisów za wszelką cenę i potrafił powiedzieć „nie” władzom okupacyjnym. Niemcy w swojej krótkowzroczności tego nie dostrzegli, a nie brakowało dowodów, że dla części społeczeństwa Piłsudski był niekwestionowanym wodzem, przywódcą obozu niepodległościowego ${ }^{90} \mathrm{i}$ autorytetem moralnym ${ }^{91}$. Ostatecznie rachuby Niemców legły w gruzach i przegrali walkę o pamięć o Piłsudskim ${ }^{92}$.

Jak oceniano skutki aresztowania Piłsudskiego? Hupka widział w nim polityka, którego aresztowanie miało „uszlachetnic" ${ }^{\prime 3}$. Było ono dla Komendanta i dla sprawy polskiej „wydarzeniem raczej szczęśliwym”, ponieważ „przez swoje socjalistyczne otoczenie, był już na drodze utraty popularności i stopniowego zużywania się w coraz większym zamęcie. Obecnie - ponieważ Niemcy go uwięzili i wywieźli, popularność jego znów urośnie - jako męczennika" ${ }^{\prime \prime}$. Takiego scenariusza obawiał się Stephan (István) Ugron, który przestrzegał 29 lipca 1917 r. przed konsekwencjami powrotu do Polski Piłsudskiego, który jako bohater narodowy rozpocząłby niebezpieczną agitację̨ ${ }^{95}$. Podobnie uważał mecenas Teofil Ciświcki, zwolennik orientacji austriackiej, autor memoriału „Upadek Piłsudskiego z punktu widzenia interesów domu Habsburgów”. Władze niemieckie poprzez aresztowanie wyrządziły mu niechcący przysługę. Piłsudskiemu nie udowodniono stosunków z ententą, a po pobycie $\mathrm{w}$ więzieniu powróci $\mathrm{w}$ aureoli męczennika i przy wyborach do sejmu znajdzie wszystko gotowe do zwycięstwa i ewentualnego wyboru na prezydenta. Czy Austria chce sąsiadować z państwem, na którego czele stanie prezydent Piłsudski czy cesarz Piłsudski? Czy zechce odstąpić mu Galicję lub mieć tam powstanie? Jeśli odpowiedź będzie negatyw-

89 J. Gaul, Czarno-żótty miraż..., s. 297-334.

$90 \quad$ G. Nowik, Odrodzenie Rzeczypospolitej..., s. 110.

91 Docenić trzeba przenikliwość księżnej Lubomirskiej, która w lutym 1917 r. widziała Piłsudskiego w różnych rolach. Pamiętnik księżnej Marii Zdzistawowej Lubomirskiej 1914-1918, Poznań 2002, s. 466.

92 G. Nowik, Odrodzenie Rzeczypospolitej..., s. 111; J. Ga ul, Czarno-żótty miraż..., s. 308-327.

93 A. Garlicki, Józef Pitsudski..., s. 302.

94 J. Hupka, Z czasów Wielkiej Wojny..., s. 307-308.

95 ÖStA/HHStA, M.d.Ä. PA I, kart. 1025, Krieg 56 c-1, k. 82, Telegramm von Ugron, Nr. 480, Warschau, 29.7.1917. 
na, zdaniem Ciświckiego, należało Piłsudskiemu przeciwstawić króla i odebrać aureolę męczennika ${ }^{96}$. W podobnym duchu utrzymane były wnioski nadkomisarza policji Franciszka Charwata z Lublina. Zatrzymanie Komendanta w chwili, kiedy jego aureola zaczynała gasnąć, spowodowało, że stał się znowu męczennikiem i bohaterem narodowym oraz zdobył sympatię, a więc nastąpiło dokładne przeciwieństwo tego, co chciano osiągnąc ${ }^{97}$.

\section{Dyktator i Naczelnik Państwa (listopad 1918-grudzień 1922)}

Zwolnienie Piłsudskiego z Magdeburga nastąpiło po wybuchu rewolucji w Niemczech ${ }^{98}$. Komendant jechał do Warszawy na „zaślubiny z państwem polskim” jako przywódca całego społeczeństwa ${ }^{99} \mathrm{i}$ bohater walk o niepodległość, a źródłem jego autorytetu było nie tylko aresztowanie i internowanie ${ }^{100}$, lecz także działalność podczas wojny i gotowość poświęceń dla sprawy polskiej. Piłsudski uważał, że był witany w Polsce za to, że ,jedyną wartością, którą ludzie wówczas mieli, jedyną moralną siłą, która ludzi do posłuszeństwa zmuszała [...] był fakt, że był on Komendantem I Brygady i wracał z Magdeburga"101.

${ }_{96}$ Ibidem, kart. 1025, Krieg 56 c/1, Verhaftung Piłsudskis (22.7.1917), Juli-August 1917. k. 96-103, Teofil Ciświcki, Der Fall Piłsudski vom Standpunkte der Interessen des Habsburgerhauses behandelt; Z. Wójcik, Siedemdziesiąt lat temu, „Tygodnik Powszechny” 1987 nr 29; J. G a ul, Czarno-żótty miraż..., s. 315316.

97 ÖStA/KA, Armeeoberkommando (AOK) Quartiermeisterabteilung (Qu. Abt.), kart. 2580, K.u.k. AOK Qu.Abt., MV Nr. 60/3, Geheim, 26.7.1917. K.u.k. MGG für das österr.-ung. Okkupationsgebiet in Polen, Gstbchef Präs., Nr. 9974, Vorgänge in Warschau - Bericht des Polizeioberkommissärs Charwat, Verschluss, geheim, Lublin, 24.7.1917; ibidem, HHStA, M.d.Ä. PA I, kart. 1025, Krieg 56 c-1, k. 41-48. Der Vertreter des k. und k. M.d.Ä. beim k. und k. MGG in Polen, Nr. 71, Stimmung der Linken anlässlich Internierung Piłsudskis, Geheim, Lublin, 24.7.1917; J. G a u l, Tajna misja nadkomisarza policji Franciszka Charwata w Warszawie (lipiec-sierpień 1917 r.), „Przegląd Historyczny” 2002, t. 93, z. 4, s. 424.

98 K. G. Ha usm a n n, Pitsudski und die Mission des Grafen Kessler in Polen. Ein Fragment deutsch-polnischer Beziehungen im November/Dezember 1918, [w:] Geschichte und Gegenwart. Festschrift für Karl Dietrich Erdmann, red. H. Boockmann, K. Jürgensen, G. Stolten berg, Neumünster 1980, s. 233-246; J. Ga u l, Polityczne aspekty uwolnienia Józefa Pitsudskiego z Magdeburga w listopadzie 1918 r., „Dzieje Najnowsze" R. 38, 2006, nr 3, s. 1-14.

99 J. Piłsudski, Pisma zbiorowe, t. VI, s. 24; t. VIII, s. 205, 250; J. Ga ul, Czarno-żótty miraż..., s. 336-337.

100 Według S. Ugrona pod koniec października 1918 r. Piłsudski stał się symbolem narodowym i obawiał się jego martyrologii bardziej niż agitacji - ÖStA/HHStA, M.d.Ä. PA I, kart. 1075, 1918, k. 471. Telegramm von Ugron, Warschau, 27.10.1918. Nr. 893. Chiffre. Streng vertraulich. Zdaniem B. Hutten-Czapskiego „w kraju uchodził za przyszłego dyktatora, którego niejedni się bali; przez wygnanie swe stał się postacią legendarną. [...] Uwięzienie ponadto usunęło go od zamieszek obu lat ostatnich i uchroniło od zrobienia sobie nieprzyjaciól”. I d e m, Sześ́dziesiąt lat, t. II, s. 597; J. Pa je w sk i, Odbudowa państwa polskiego..., s. 297-298; A. Ga rl ick i, JózefPitsudski..., s. 302; W. Su lej a, JózefPitsudski, s. 171; G. Now i k, Odrodzenie Rzeczypospolitej..., s. 91.

101 J. Piłsud ski, Pisma zbiorowe, t. VI, s. 27. W początkach listopada 1918 r. entuzjazm dla „wodza narodu” podzielali także dowborczycy. M. Romeyko, Przed i po maju, Warszawa 1967, s. 80-81; G. Nowik, 
Objął urząd w momencie braku władzy politycznej cieszącej się zaufaniem kraju, gdyż „Rada Regencyjna pozbawiona autorytetu swoją polityką uparcie aktywistyczną, była otoczona ze wszystkich stron wrogimi sobie nastrojami, gotowymi usunąć ją siłą, krajowi zaś groził chaos". Potrzebne było też wojsko, by złączyć wszystkie dzielnice Polski i bronić jej granic ${ }^{102}$.

Kontrowersje wywoływała dyktatura Piłsudskiego, której obawiano się już wcześniej. Jaworski przewidywał w październiku 1918 r. „walki na noże między Dmowskim a Piłsudskim” i „może przejściowej dyktatury Piłsudskiego” ${ }^{103}$. Sprawdził się jego scenariusz, że Piłsudski zwróci się przeciwko bolszewizmowi, a Narodowa Demokracja ze strachu przed bolszewizmem podda się mu. O ile nie mylił się, że „Demokracja Narodowa będzie czyniła wszystko, aby go usunąć”, o tyle fałszywie ocenił Komendanta, że „on wtedy, właśnie dlatego, zwiąże się z bolszewikami"104. Hupka, przeciwnie, nadzieję zaprowadzenia porządku w Polsce pokładał w Piłsudskim, a w jego dyktaturze widział tamę przeciw rewolucji ${ }^{105}$. Narodowa Demokracja, krytykując dekret z 22 listopada 1918 r., traktowała władzę Piłsudskiego jako uzurpatorską, gdyż „bez rządu narodowego sprawa najwyższej władzy w Polsce została tymczasowo rozwiązana w formie dyktatury jednej osoby" ${ }^{106}$.

Piłsudski uważał, że został dyktatorem nie na drodze gwałtu i narzucenia swojej władzy lub swobodnego wyboru ludzi w ciężkiej sytuacji, jak to było w klasycznych dyktaturach, tylko w wyniku „moralnej pracy narodu” milionów ludzi, którzy go słuchali ${ }^{107}$. Według ambasadora Wacława Grzybowskiego w listopadzie 1918 r. Piłsudski na podstawie niemal jednomyślnej decyzji wszystkich warstw społeczeństwa został obarczony bezprzykładną, nieograniczoną władzą ${ }^{108}$. Obywatele docenili jego działalność w latach I wojny światowej, gotowość poświęceń dla sprawy polskiej i obdarzyli „dyktatora moralnego” godnością Tymczasowego Naczelnika Państwa ${ }^{109}$.

Odrodzenie Rzeczypospolitej..., s. 113-116. Nie brak było negatywnych opinii. Dziennik Juliusza Zdanowskiego, t. II, s. 177.

102 W. Baranowski, Rozmowy z Pitsudskim..., s. 60.

103 W. L. Jaw orski, Diariusz 1914-1918, s. 286.

104 Ibidem, s. 287.

105 J. Hupka, Z czasów Wielkiej Wojny..., s. 372-373.

106 S. Głąbiński, Wspomnienia polityczne, Pelplin 1939, s. 383.

107 J. Piłsudski, Pisma zbiorowe, t. VI, s. 28.

108 W. Gr zy bow ski, Samotność Józefa Pitsudskiego (Kilka uwag i wspomnień), „Niepodległość” 1972, t. VIII, s. 172; W. T. D r y m m e r, Pierwsze i ostatnie dni niepodlegtości - rok 1918 i 1939, „Zeszyty Historyczne” 1969 , z. 16, s. 152. S. Głąbiński przytacza tekst z „Kuriera Warszawskiego” z 12 listopada: „Piłsudski stał się personifikacją idei jedności narodowej [...]. Jeśli komendant znajdzie zaklęcie, łamiące uprzedzenia i sprzęgające ramiona, to naród zdobędzie się na najwyższy wysiłek, a przyszłość jego będzie zabezpieczona i szczęśliwa”. I d e m, Wspomnienia polityczne, s. 375.

109 B. Hutten-Czapski pisał: „Jestem przekonany, iż byłby mógł dać się okrzyknąć Królem. [...] Okoliczność, iż pomimo nieograniczonej władzy pozostał prostym żołnierzem, jakim był, tylko podniosła jego popu- 
Stosunek Piłsudskiego do dyktatury pokazuje sprzeciw na propozycję jej przedłużenia. Władysław Baranowski, zapowiadając powrót Piłsudskiego z Magdeburga w komunikatach agencji „Polonia”, pisał, że obejmie on władzę dyktatorską, a przy pomocy powołanej ad hoc Rady Stanu sprawować będzie rządy do czasów, gdy sytuacja pozwoli na normalną organizację państwa na zasadach demokratycznych ${ }^{110}$. Współpracownicy Komendanta uważali, że „wzięcie w karby” społeczeństwa byłoby o wiele bardziej wskazane niż zapowiedziane wybory, których wynik nie był pewny ${ }^{111}$. Dla Piłsudskiego przedłużenie stanu dyktatorskiego było sprzeczne z poczuciem wolności, ale przede wszystkim stwarzało sytuację bez prawa, co mogłoby zaszkodzić Polsce w opinii świata ${ }^{112}$. Uważał, że należy jak najszybciej sytuację w Polsce „ulegalizować na zewnątrz i wewnątrz”. Wierzył, że społeczeństwo „się uspokoi”, a zagranica zobaczy, że nikt nie chce w Polsce robić bolszewizmu ${ }^{113}$.

Ważnym elementem wypełniania funkcji Naczelnika Państwa było wyjście poza dyktaturę osobistą czy partyjną. Od odzyskania przez Polskę niepodległości i od objęcia urzędu Naczelnika Piłsudski przestał się definitywnie uważać za członka PPS ${ }^{114}$, czuł się reprezentantem ogółu obywateli. Parafrazując znane powiedzenie, że wysiadł on z czerwonego tramwaju socjalizmu na przystanku niepodległości, można dodać, że opuścił także przedział przywódcy partyjnego na przystanku męża stanu. Uważał, że lewica dostała wszystko, czego zapragnąć mogła, i tylko od niej zależało wprowadzenie do sejmu swojej większości dla zachowania dorobku rządu Jędrzeja Moraczewskiego. W dalszej perspektywie należało dążyć do rządu koalicyjnego, „wobec ważkich i ciężkich zagadnień, które nas czekają, zwłaszcza wobec konferencji pokojowej, jak i niebezpieczeństw które czyhają"115. Na wątpliwości Baranowskiego Piłsudski odpowiedział, że wcześniejsze próby zjednoczeniowe uniemożliwiały spory orientacyjne, wierzył jednak, że w końcu dojdzie do „union sacrée”, choćby na krótki czas, w obliczu wielkich zadań i niebezpieczeństw ${ }^{116}$.

larność". Id em, Sześ́dziesiąt lat, t. II, s. 597. Krytyka Piłsudskiego podyktowana była jego współpracą z państwami centralnymi. Dziennik Juliusza Z danowskiego, s. 52-53.

110 W. B a ranowski, Rozmowy z Pitsudskim..., s. 51.

111 Ibidem.

112 Dnia 21 listopada 1918 r. Kessler usłyszał od Piłsudskiego zapowiedź ustanowienia w kraju porządku konstytucyjnego i złożenia władzy dyktatorskiej. K. G. Haus ma nn, Pitsudski und die Mission..., s. 251. Piłsudski odrzucił pokusę wmówienia ludziom, że w imię wolności można rządzić niedemokratycznie, chociaż przynosiło to efekty. G. Le Bon (op. cit., s. 52) pisał: „Każdy mąż stanu powinien rzeczom, których tłumy nie mogą ścierpieć, a których istnienia dla dobra narodu nie da się wyrugować, nadawać nowe nazwy i dbać, aby były popularne lub przynajmniej obojętne".

113 W. B a ranowski, Rozmowy z Pitsudskim..., s. 52;.

114 S. Skwarczyński, Przemiany duchowe..., s. 4-11.

115 W. Ba ra now ski, Rozmowy z Pitsudskim..., s. 52.

116 Ibidem. W. L. Jaworski widział bezpodstawnie 12 listopada Piłsudskiego na usługach rewolucji: „Nominacja Piłsudskiego rodzajem dyktatora niewątpliwa w swych skutkach. Nie zdecyduje się strzelać do bolszewików, a wskutek tego nie uchroni nas od wstrząśnień. Oprócz tego wyrzuci z armii polskiej najlepsze 
Piłsudski, jak przystało na dyktatora, wydawał edykty i rozkazy, mianował urzędników wojskowych i cywilnych ${ }^{117}$. Jego rządy od listopada 1918 do lutego 1919 r. były przykładem dyktatury w stylu rzymskim ${ }^{118}$. Według Jüngera do klasycznych oznak dyktatury należała jej legalność. „Dyktatura winna zlikwidować konkretną bolączkę, stąd czas jej trwania miał być ograniczony. Jej zadanie nie polega jednak na zmianie abstrakcyjnego stanu negatywnego, a zatem nie może działać pod dyktando ideologii. Dyktator wykonuje najkonieczniejszą pracę, a podczas jej realizacji wyrazista wola łączyć się winna ze zdrowym rozsądkiem [...]"119. Piłsudski sam określił czas i cel sprawowania władzy: zbudowanie zrębów państwowości polskiej i przeprowadzenie wyborów do Sejmu Ustawodawczego, co nastąpiło 26 stycznia 1919 r. Podporządkowal się wybranym przez naród reprezentantom ${ }^{120}$.

Gdy w grę wchodziło dobro ojczyzny, Piłsudski był gotów na kompromis. Stawiając na pierwszym miejscu sprawę ugruntowania państwowości polskiej i obrony jej granic, przyjął 20 lutego 1919 r. ponownie godność Naczelnika Państwa od Sejmu Ustawodawczego ${ }^{121}$. Jego przeciwnicy w imię interesów osobistych i partyjnych zdecydowali się ograniczyć kompetencje Naczelnika tylko do reprezentacji państwa i spraw wojskowych, pospiesznie uchwalając 20 lutego 1919 r. Małą Konstytucję ${ }^{122}$. Piłsudski podkreślił fakt wybrania go bez jego starań i zabiegów jednogłośnie na Naczelnika Państwa, „nie mając żadnego innego w Polsce zaszczytu, oprócz mojej poprzedniej dyktatury"123.

Gotowość Piłsudskiego do kompromisu miała granice. Właściwe wypełnianie funkcji Naczelnika Państwa wymagało wzniesienia się z poziomu polityka do poziomu męża

elementy". Id e m, Diariusz 1914-1918, s. 296. Według W. Sulei Piłsudski pragnął po powrocie do kraju odegrać rolę koordynatora narodowego wysiłku. Id e m, Józef Pitsudski, s. 179. Nie było to łatwe zadanie wobec nieustępliwej postawy narodowych demokratów, domagających się powołania rządu narodowego. S. Głąbiński, Wspomnienia polityczne, s. 376-381.

117 J. Piłsudski, Pisma zbiorowe, t. VI, s. 26-27; W. Su leja, Józef Pitsudski, s. 180.

118 J. Piłsudski, Pisma zbiorowe, t. VI, s. 188-189; t. VIII, s. 307-308, 322-323.

119 E. Jünger, Węzet gordyjski. Eseistyka lat pięćdziesiątych, tłum. i oprac. W. Ku n icki [et al.], Kraków 2013, s. 183-184: „W świecie rzymskim dyktator musiał jako mąż stanu piastować urzędy, musiał dowodzić w bitwach. Nie był jak Lenin, Mussolini czy Hitler politykiem z programem partyjnym, który koniecznie należało zrealizować. Fakt, że Franco utrzymał się dłużej niż Hitler czy Mussolini, wyjaśnić można między innymi jego brakiem programu".

120 J. Piłsudski, Pisma zbiorowe, t. V, s. 55; t. VI, s. 28.

121 S. Ku tr ze ba, Polska odrodzona 1914-1939, Kraków 1988, s. 119-120; A. Pró ch n ik, Pierwsze piętnastolecie Polski niepodlegtej (1918-1933), Warszawa 1983, s. 54-55.

122 S. Głąbiński (Wspomnienia polityczne, s. 423-429) przyznał, że Mała Konstytucja zaogniła antagonizm między Naczelnikiem Państwa i większością sejmową, „wskutek zepchnięcia Piłsudskiego, dotychczasowego dyktatora, na drugorzędne stanowisko formalnego przedstawiciela państwa”. S. Ku tr ze ba, Polska odrodzona 1914-1939, s. 119-120; A. Próchnik, Pierwsze piętnastolecie..., s. 54-55; W. Suleja, Józef Pitsudski, s. 195-196; G. Nowik, Odrodzenie Rzeczypospolitej..., s. 298-310.

123 J. Piłsudsk i, Pisma zbiorowe, t. VI, s. 29. Według W. Sulei pomysłodawcą tytułu Naczelnika Państwa, sięgającego czasów insurekcji kościuszkowskiej, był radca z TRS Stanisław Bukowiecki. Id e m, Józef Pitsudski, s. 181. 
stanu. Droga powrotna byłaby wyrzeczeniem się wyznawanych wartości. Piłsudski obawiał się, że Sejm Ustawodawczy, niemający po wyborach większości, która tworzyć się będzie od przypadku do przypadku, zwróci się do niego jako do polityka. Gdyby chciał go zmusić do odgrywania takiej roli, wtedy jedynym możliwym rozwiązaniem byłoby ustąpienie z urzędu. „Zajmowanie się sprawami państwowymi, w których nie mogę przeprowadzić jednolitej linii ani w polityce zagranicznej, ani w sprawach wojskowych - w dziedzinach więc podstawowych dla każdego państwa i wymagających nieodzownej jednolitości - postawiłoby mnie $\mathrm{w}$ fałszywe wobec samego siebie położenie, byłoby sprzecznym z moim własnym sumieniem"124.

Piłsudski wielokrotnie deklarował publicznie swoje credo: ,jako Naczelnik Państwa, nie mogę być naczelnikiem ani żadnej grupy lub stronnictwa, ani też jakiegokolwiek miasta; jestem Naczelnikiem całego narodu i wszystkich jego warstw" (10 stycznia 1920 r. $)^{125}$. Podobnie odnosił się do mniejszości narodowych ${ }^{126}$. Reprezentowanie wszystkich obywateli Rzeczypospolitej nakładało ograniczenia na Naczelnika Państwa. Inaczej było z funkcją Naczelnego Wodza. W trakcie kryzysowych dni w lipcu 1920 r., związanych z planami narodowych demokratów i lewicy przeprowadzenia zamachów stanu ${ }^{127}$, Piłsudski jako Naczelnik Państwa mógł trzymać na wodzy obie strony. Nie krył jednak, że podczas ewentualnej wojny domowej tylko jako Naczelny Wódz będzie miał wolną rękę „przechylenia szali zwycięstwa na stronę lewicy, ale lewicy temperowanej, gdyż przeciw nieutemperowanej będzie musiał wystawić karabiny" ${ }^{\prime 28}$.

Zapleczem męża stanu powinien być cały naród. Trzymanie równego dystansu do głównych sił politycznych nie spotkało się ze zrozumieniem, a ponadto skutkowało brakiem szerokiego zaplecza ${ }^{129}$. Piłsudski odrzucił w 1922 r. koncepcję budowania własnego ugrupowania, które włączyłoby się w walkę o władzę. Nie miał też zamiaru tworzenia programu ideologicznego. Nadrzędną wartością było dla niego państwo polskie, któremu służył wiernie. Piłsudski miał świadomość, że był wodzem i pragnął, by prawda ta znalazła zrozumienie w całym społeczeństwie, a nie tylko wśród jego zwolenników ${ }^{130}$.

Jako wytrawny polityk wiedział, że nie u wszystkich cieszył się popularnością: „,wzbudzał dla siebie łatwo bardzo silne uczucie przywiązania czy nienawiści, natomiast nie wytwarzał

${ }_{124}$ Listy Józefa Pitsudskiego, wstęp K. Św it a lsk i, „Niepodległość” 1962, t. 7, s. 12; W. Su l e ja, Józef Pitsudski, s. 194-195.

125 J. Piłsudski, Pisma zbiorowe, t. V, s. 135.

126 Ibidem, s.155.

127 J. Cisek, O planie zamachu na Józefa Pitsudskiego w sierpniu 1920 roku, „Niepodległość” 1991, t. 24, s. 7-14.

128 K. Św it alski, Diariusz. Uzupetnienia z lat 1919-1932, Warszawa 2012, s. 36.

129 A. Garlicki widział w Piłsudskim polityka, a nie męża stanu. Id e m, Józef Pitsudski..., s. 359; J. Mol en da, Pitsudczycy..., s. 489-490; D. Le c zy k, Druga Rzeczypospolita..., s. 170-171, 359.

130 W. Suleja, Józef Pitsudski, s. 260-261. 
zrozumienia dla swoich myśli i zamiarów"131. Trudno się dziwić, że prawie jednomyślne poparcie dla Piłsudskiego u progu niepodległości trwało krótko ${ }^{132}$. Szybko wzbierała fala niezrozumienia i niechęci ze strony przeciwników politycznych. „Samotność tym razem podwójna, zarówno męża stanu jak i wodza, bierze nieubłagany i niemal natychmiastowy odwet. Nawet za bezprzykładne zwycięstwo zapłacą mu uchwaleniem konstytucji, skierowanej przeciw jego władzy"133.

Podsumowując, status męża stanu nie jest łatwo osiągnąć, bo nie wystarczy być skutecznym politykiem. Trzeba wznieść się ponad interes osobisty i partyjny, reprezentować całe społeczeństwo i ojczyznę, stać konsekwentnie na gruncie najwyższych wartości, realizując rację stanu. Taka postawa wyniosła Piłsudskiego na szczyty sławy, zarazem zmuszała do podejmowanie trudnych decyzji. Gdy zachowanie imponderabiliów nie wchodziło w grę, pozostawała dymisja. Wielu polityków polskich nie rozumiało, że Piłsudski potrafił powiedzieć „nie” w obronie nadrzędnej wartości, jaką było demokratyczne państwo polskie dla wszystkich obywateli, bez wykluczenia ze względu na wyznanie, język czy rasę, europejskie, związane z Zachodem, a nie Wschodem. Do realizacji takiego programu nie wystarczała dobra wola przywódcy, potrzebne było szerokie poparcie społeczne. Piłsudski, będąc mężem stanu, który chciał służyć ojczyźnie, a nie być listkiem figowym dla partyjnych elit, przegrywał jako polityk, bo odcinał się od partii, tracił poparcie działaczy i wyborców, których na dłuższą metę wzniosłe ideały i „upojenie odzyskaną wolnością” nie skłaniały do rezygnacji z zaspokajania własnych korzyści i interesów. Po odrzuceniu przez prawicę narodową jego statusu męża stanu i wodza ustąpił w latach 1922-1923 ze wszystkich urzędów. Wkrótce zaczął się szykować ponownie do roli dyktatora, aby przeprowadzić sanację państwa. Było to możliwe, gdyż Piłsudski nie stracił w znacznej części społeczeństwa autorytetu. Wykorzystał to w maju 1926 r., kiedy nie tylko zdobył siłą władzę, ale też skutecznie ją zalegalizował.

\section{BIBLIOGRAFIA}

\section{Źródła drukowane:}

Galicyjska dziatalnośc wojskowa Pitsudskiego 1906-1914. Dokumenty, wybór i oprac. S. Arski, J. Chudek, Warszawa 1967.

Gierowska-Kałłaur J., Odczyt Marszatka Pitsudskiego wygtoszony 24 sierpnia 1923 roku w Wilnie, „Przegląd Wschodni” 1998, t. 5, z. 4, s. 770-778.

131 K. Świtalsk i, Diariusz 1914-1935, Warszawa 1992, s. 107; W. Su le ja, Józef Pitsudski, s. 261.

132 Ta wojna zmieni wszystko... Dziennik Janiny Gajewskiej, oprac. A. Wajs, Warszawa 2014, s. 305.

133 W. Grzybowski, Samotność Józefa Pitsudskiego..., s. 172. S. Thugutt pisał o walce z endekami, „którzy przy układaniu Konstytucji [marcowej - JG] chcieli ją mieć za narzędzie, odbierające Naczelnikowi Państwa wszelką możność działania dlatego, że nim był Piłsudski". Id e m, Autobiografia, s. 134-135; S. Głąbiński, Wspomnienia polityczne, s. 490-499. 
Listy Józefa Pitsudskiego, wstęp K. Świtalski, „Niepodległośč 1962, t. 7, s. 5-126.

Piłsudski J., Korespondencja 1914-1917, oprac. S. Biegański, A. Suchcitz, Londyn 1984.

Piłsudski J., Pisma zbiorowe, t. I-X, Warszawa 1937-1938.

Wyjątki z listów Marszatka Józefa Pitsudskiego, „Niepodległość” 1948, t. 1, s. 9-11.

\section{Wspomnienia:}

Baranowski W., Rozmowy z Pitsudskim 1916-1931, Warszawa 1990.

Boerner I., Z pamiętnika, „Niepodległość” 1938, t. 17, s. 195-200.

Daszyński I., Pamiętniki, t. II, Warszawa 1956.

Dąbrowska M., Dzienniki 1914-1925, t. I, Warszawa 1998.

Drymmer T. W., Pierwsze i ostatnie dni niepodlegtości - rok 1918 i 1939, „Zeszyty Historyczne” 1969 , z. 16, s. 147-163.

Dubiel F., Pamiętnik wojenny 1916-1917, [w:] J. Skrzypczak, Idea i czyn. Drogi mielczan do niepodlegtości 1907-1918, Mielec 2003, s. 143-266.

Dziennik Juliusza Zdanowskiego, t. II: 15 X 1918-23 VI 1919, przedmowa i oprac. J. Faryś [et al.], Szczecin 2014.

Głąbiński S., Wspomnienia polityczne, Pelplin 1939.

Grzybowski W., Samotność Józefa Pitsudskiego (Kilka uwag i wspomnień), „Niepodległość” 1972, t. 8, s. $167-175$.

Hupka J., Z czasów Wielkiej Wojny. Pamiętnik nie kombatanta, Niwiska 1936.

Hutten-Czapski B., Sześ́́dziesiąt lat życia politycznego i towarzyskiego, t. I-II, Warszawa 1936.

Jaworski L. W., Diariusz 1914-1918, wybór i oprac. M. Czajka, Warszawa 1997.

Jędrzejewicz W., O Pitsudskim, Legionach i POW w PRL, „Zeszyty Historyczne” 1985, z. 74, s. $192-201$.

Komornicki S., Fragmenty pamiętnika Stanistawa Downarowicza, „Zeszyty Historyczne” 1975, z. 33, s. 97-104.

Moraczewski J., Przewrót w Polsce, Warszawa 2015.

Pamiętnik Hermana Diamanda zebrany z wyjątków listów do żony, Kraków 1932.

Pamiętnik księżnej Marii Zdzistawowej Lubomirskiej 1914-1918, Poznań 2002.

Piłsudska A., Wspomnienia, Warszawa 1989.

Romeyko M., Przed i po maju, Warszawa 1967.

Starzyński S., Cztery lata wojny w stużbie Komendanta. Przeżycia wojenne 1914-1918, Warszawa 2012.

Świtalski K., Diariusz 1916-1917, cz. 2, „Niepodległość” 1996, t. 48, s. 3-80.

Świtalski K., Diariusz 1919-1935, Warszawa 1992.

Świtalski K., Diariusz. Uzupetnienie z lat 1919-1932, przedmowa i oprac. P. Duber, W. Suleja, Warszawa 2012.

Ta wojna zmieni wszystko... Dziennik Janiny Gajewskiej, oprac. A. Wajs, Warszawa 2014.

Thugutt S., Autobiografia, Warszawa 1984.

Wieniawa-Długoszowski B., Wymarsz i inne wspomnienia, [Łomianki] 2012.

\section{Opracowania:}

Cisek J., O planie zamachu na Józefa Pitsudskiego w sierpniu 1920 roku, „Niepodległość” 1991, t. 24, s. 7-14.

Duroselle J.-B., Wielka wojna Francuzów 1914-1918, tłum. A. Ciastek, Warszawa 2006.

Friszke A., O ksztatt niepodlegtej, Warszawa 1989. 
Garlicki A., Geneza legionów. Zarys dziejów Komisji Tymczasowej Skonfederowanych Stronnictw Niepodlegtościowych, Warszawa 1964.

Garlicki A., Józef Pitsudski 1867-1935, Kraków 2009.

Garlicki A., U źródet obozu belwederskiego, Warszawa 1979.

Gaul J., Czarno-żótty miraż. Sprawa Józefa Pitsudskiego w monarchii habsburskiej 1896-1918, Warszawa 2018.

Gaul J., Józef Pitsudski an der Schwelle zur Unabhängigkeit Polens. Siegreich als Staatsmann - besiegt als Politiker (1914-1922), [w:] 1918 - Das letzte Kriegsjahr. Symposium 9. November 2018, Wien 2019, s. 63-97.

Gaul J., Na tajnym froncie. Dziatalność wywiadowczo-informacyjna obozu niepodlegtościowego w latach 1914-1918, Warszawa 2001.

Gaul J., Polityczne aspekty uwolnienia Józefa Pitsudskiego z Magdeburga w listopadzie 1918 r., „Dzieje Najnowsze" R. 38, 2006, nr 3, s. 1-14.

Gaul J., Przez zaborcza Austrię do niepodlegtej Polski. Militarny, polityczny i cywilizacyjny wymiar polskiej racji stanu 1867-1918, „Przegląd Wschodni” 2019, t. 58, s. 235-271.

Gaul J., Tajna misja nadkomisarza policji Franciszka Charwata w Warszawie (lipiec-sierpień 1917 r.), „Przegląd Historyczny” 2002, t. 93, z. 4, s. 413-438.

Grosfeld L., Polityka panstw centralnych wobec sprawy polskiej w latach pierwszej wojny światowej, Warszawa 1962.

Hausmann K. G., Pitsudski und die Mission des Grafen Kessler in Polen. Ein Fragment deutsch-polnischer Beziehungen im November/Dezember 1918, [w:] Geschichte und Gegenwart. Festschrift für Karl Dietrich Erdmann, red. H. Boockmann, K. Jürgensen, G. Stoltenberg, Neumünster 1980, s. 233-276.

Hausner A., Die Polenpolitik der Mittelmächte und die österreichisch-ungarisch Militärverwaltung in Polen während des Weltkrieges, Wien 1935.

Holzer J., Molenda J., Polska w pierwszej wojnie światowej, Warszawa 1973.

Jabłonowski M., Kossewska E., Pitsudski na tamach prasy bytych wojskowych, [w:] Pitsudski na tamach i w opiniach prasy polskiej 1918-1989, red. M. Jabłonowski, E. Kossewska, Warszawa 2005, s. 97-118.

Jędrzejewicz W., Cisek J., Kalendarium życia Józefa Pitsudskiego 1867-1935, t. III: 1921-1926, Kraków-Łomianki 2007.

Jünger E., Robotnik, tłum. W. Kunicki, Warszawa 2017.

Jünger E., Węzet gordyjski. Eseistyka lat pięćdziesiątych, tłum. i oprac. W. Kunicki [et al.], Kraków 2013.

Kochanowski J., Powotanie Józefa Pitsudskiego do Tymczasowej Rady Stanu w świetle korespondencji wtadz austriackich (na marginesie artykutu Ryszarda Świętka, Polityka Józefa Pitsudskiego wobec aktu 5 listopada 1916, „Przeglad Historyczny”, t. 77, 1988, z. 1, s. 71-95), „Przegląd Historyczny" 1988 , t. 79, z. 3, s. 531-537.

Król M., Wielcy wtadcy, Warszawa 2014.

Kutrzeba S., Polska odrodzona 1914-1939, Kraków 1988.

Le Bon G., Psychologia ttumu, tłum. B. Kaprocki, Kęty 2005.

Leczyk M., Druga Rzeczpospolita 1918-1939. Spoteczeństwo. Gospodarka. Kultura. Polityka, Warszawa 2006.

Miodowski A., Sprawozdanie z I Ogólnego Zjazdu Delegatów Wojskowych Polaków w Rosji (7.0622.06.1917 r.), „Studia Podlaskie”2000, t. 10, s. 233-279, https://doi.org/10.15290/ sp.2000.10.11. 
Molenda J., Pitsudczycy a narodowi demokraci 1908-1918, Warszawa 1980.

Nowik G., Odrodzenie Rzeczypospolitej w myśli politycznej Józefa Pitsudskiego 1918-1922. Część I Sprawy wewnętrzne, Warszawa 2018.

Pająk Z. J., O rząd i armię. Centralny Komitet Narodowy (1915-1917), Kielce 2003.

Pajewski J., Budowa Drugiej Rzeczypospolitej 1918-1926, Poznań 2007.

Pajewski J., Odbudowa państwa polskiego 1914-1918, Warszawa 1978.

Pethö A., Agenten für den Doppeladler. Österreich-Ungarns Geheimer Dienst im Weltkrieg, GrazStuttgard 1998.

Próchnik A., Pierwsze piętnastolecie Polski niepodlegtej (1918-1933), Warszawa 1983.

Pruszyński M., Tajemnica Pitsudskiego, Warszawa 1997.

Rauchensteiner M., Der Erste Weltkrieg und das Ende der Habsburgermonarchie 1914-1918, WienKöln-Weimar 2013, https://doi.org/10.7767/boehlau.9783205789628.

Rzegocki A., Racja stanu a polska tradycja myślenia o polityce, Kraków 2008.

Rzepecki J., O Wtadystawie Sikorskim w Legionach. Zakończenie, „Wojskowy Przegląd Historyczny” 1966, t. 11, z. 1, s. 211-240.

Rzewuski P., Filozofia Pitsudskiego, Warszawa 2018.

Skwarczyński S., Licytacja sprawy polskiej wzwyż. Podstawy i metody politycznej dziatalności Józefa Pitsudskiego w okresie pierwszej wojny światowej, „Niepodległość” 1972, t. 8, s. 13-25.

Skwarczyński S., Przemiany duchowe Józefa Pitsudskiego w latach 1905-1922, „Niepodległość” 1976, t. 10, s. 3-16.

Snopko J., Finat epopei Legionów Polskich 1916-1918, Białystok 2008.

Suleja W., Józef Pitsudski, Wrocław 1995.

Suleja W., Orientacja austro-polska w latach I wojny światowej (do aktu 5 listopada 1916 roku), Wrocław 1992, Acta Universitatis Wratislaviensis, nr 1421, Historia, t. 103.

Świętek R., Lodowa ściana. Sekrety polityki Józefa Pitsudskiego 1904-1918, Kraków 1998.

Urbankowski B., Józef Pitsudski: marzyciel i strateg, Poznań 2014.

Wójcik Z., Siedemdziesiąt lat temu, „Tygodnik Powszechny” 1987, nr 29.

Wrzosek M., Dążenia austriackich i niemieckich czynników wojskowych do wyeliminowania Józefa Pitsudskiego z gry politycznej o sprawe polska podczas I wojny światowej (czerwiec 1915-lipiec 1917), [w:] Lata Wielkiej Wojny. Dojrzewanie do niepodlegtości 1914-1918, red. D. Grinberg, J. Snopko, G. Zackiewicz, Białystok 2007, s. 259-278.

Wrzosek M., Polski czyn zbrojny podczas pierwszej wojny światowej 1914-1918, Warszawa 1990. 